\title{
A HANDBOOK OF THE FUNGUS DISEASES OF WEST INDIAN PLANTS
}

(WITH SIX ILIUUSTRATED PLATES)

BY

KEITH BANCROFT, B.A.

LONDON :

GEO. PULMAN AND SONS, LTD., THAYEK STREET, W.

$\overline{1910 .}$ 


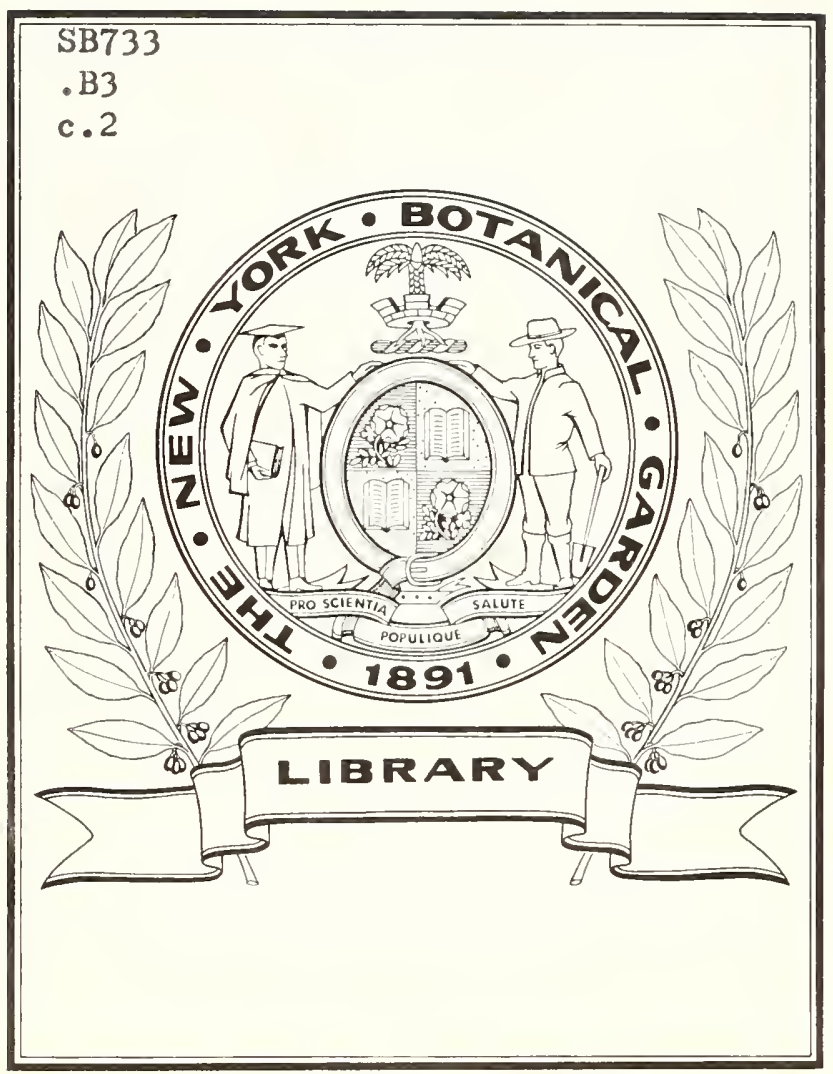






\title{
A HANDBOOK OF THE FUNGUS DISEASES OF
}

\section{WEST INDIAN PLANTS}

\author{
BY \\ KEITH BANCROFT, B.A. \\ (Barbados Scholar, 1905 ; Major Scholar of Trinity \\ College, Cambridge, r 908 ; Assistant \\ Mycologist to the Federated \\ Malay States)
}

\section{I.MPARY \\ int is YCose}


58733

.$B 3$

E. 2 


\section{PREFACE.}

DURING the past year the author of the following pages has been engaged, by kind permission of the Director of the Royal Gardens, Kew, in mycological work at the Jodrell Laboratory. This work, carried out under the guidance and advice of Mr. George Massee, V.M.H., Chief Assistant at the Royal Herbarium and Plant Pathologist to the Board of Agriculture, has included a study of a considerable mass of material sent to Kew from various tropical colonies, and has led the author to make for his own use a general survey of the principal West Indian fungus diseases of plants, and also of other tropical fungus diseases. The following pages are published with the hope that they may prove useful as a summary to workers in tropical agricultural departments, and that there may be set before the planters in the West Indies an account of the pathological effects caused by their fungus pests and an indication of the methods of treatment which have been recommended from time to time.

It has been thought fit to include along with the diseases which have been reported to occur in the West Indies the more important diseases of the same crops when they are cultivated in other parts of the world.

The introduction contains some general remarks on parasitic fungi, a brief discussion of the methods of treatment most commonly in use for fungus diseases and an indication of the more important problems which are connected with the study of plant pathology in the West Indies at the present time.

A diagnosis of each parasitic fungus has been given wherever it was possible to do so, and, in the more important diseases, the methods of treatment which have been actually recommended, or which would appear likely to prove effective, have been included. 
The more important references have been appended under each disease, and six illustrated plates have been prepared.

The ground covered by the parts dealing with West Indian parasitic fungi is much the same as that contained in a paper recently contributed to the West Indian Bulletin, published in Vol. X., No. 3, of that journal under the author's name, and entitled "Fungi Causing Diseases of Cultivated Plants in the West Indies." A word of explanation, therefore, appears necessary with regard to certain not inconsiderable differences between that paper and this book. Owing to the loss of time incident to transmitting the paper to England before its publication in the West Indian Bulletin, the author was not referred to in connexion with certain modifications and alterations which were made by the Imperial Mycologist to the West Indian Department of Agriculture; the paper published in the West Indian Bulletin, therefore, did not altogether express the author's views on the fungus diseases of the West Indies.

The author is much indebted to the Director of the Royal Botanic Gardens, Kew, for his kindness in permitting the work to be done at the Jodrell Laboratory, and to Mr. George Massee for the great kindness which he has. shown in directing the work. 


\section{INTRODUCTION.}

General.... The fungus diseases of the West Indies may be said to furnish no exception to the general statement that the plant diseases of tropical countries are very numerous, and apparently more formidable than those of the temperate regions. Although there has been no actual instance of an epidemic approaching in magnitude the classical example furnished by the leaf disease of the coffee plant in Ceylon in the years I875-1885, yet considerable loss has been suffered from time to time owing to the attacks of fungi. The best-known instance is probably the "rind fungus of the sugar cane," Trichosphaeria Sacchari, which did considerable damage to the sugar industry in the years I 895-1900; second to this is Marasmius Sacchari, "root fungus of the sugar cane," which was especially prominent in Barbados in I904; Diplodia cacaoicola, "dicback and brown pod fungus of cacao," and Phytophthore omnivora, "black pod fungus of cacao," have also caused much damage to the cacao industry in the Islands.

Several of the parasitic fungi of the West Indies have a wide area of geographical distribution; Diplodia cacaoicola and Phytophthora omnivora have been reported to occur practically wherever the cacao plant is cultivated, Trichospharia Sacchari occurs in India, Java, Mauritius and Queensland, Colletotrichum falcatum, "red rot fungus of sugar cane," is known in India, Java, Hawaii and Queensland, Spharostilbe flavianm, "leaf fungus of coffee," is spread over tropical America, and many others are less widely distributed. The diagram on the opposite page indicates the distribution of some of the more important parasites of sugar cane and cacao.

The two most important plant industries of the West Indies are the cultivation of sugar cane and of cacao; other crops which are cultivated for export are banana, cotton, orange, lime, coffee, and coconut, while others still, such as eddoe, yam, sweet potato, breadfruit, and mango are grown principally for internal consumption. Of these crops sugar cane and cacao suffer more severely from the attacks of fungi than any of the others; and the fungus pests of cacao, principally on account of the perennial nature of the plant, are more difficult to cope with than those of the sugar cane. 


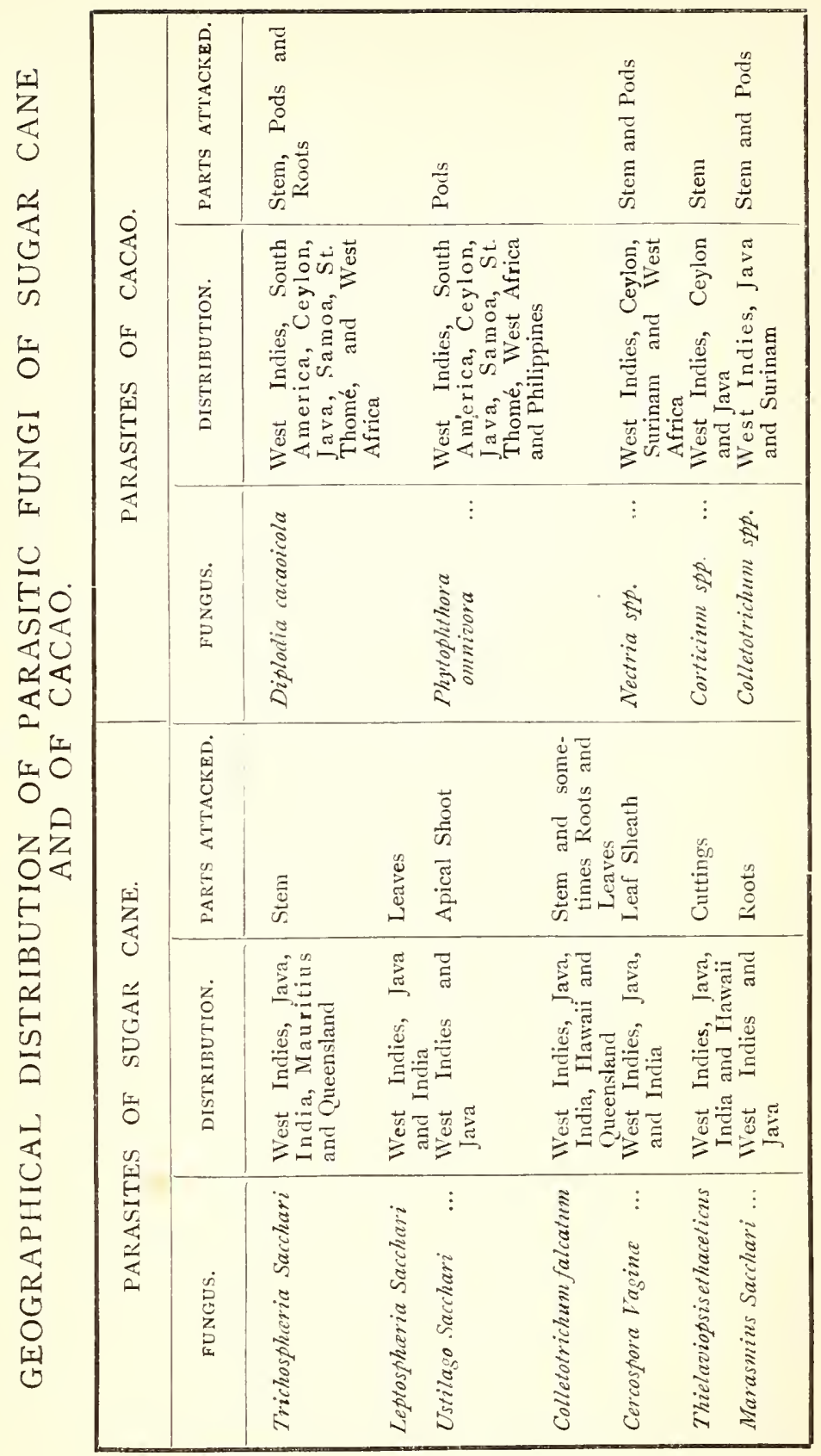


The area of cacao under cultivation in the tropics is, comparatively speaking, large and continues to increase from year to year; this must eventually lead to very severe competition, and those countries will hold their own which have efficient methods of cultivation, good and cheap labour, etc., which can produce the best varieties and last, but by no means least, which are able to keep their pests under control. It is for this reason that the fungi parasitic on cacao should demand the most careful attention of the mycologist.

Methods of Treatment.-Throughout the tropical world it is gradually becoming more generally recognised that careful treatment of plant diseases is necessary for the successful cultivation of economic plants. As with the study of human and animal pathology, so with plant pathology, the practice resolves itself into the careful observation of the causes and symptoms before the remedial means can be suggested. For the successful treatment of fungus disease a knowledge of the life-history of the fungus causing the disease is of primary importance, in order to know when to attack the fungus, how to diminish the conditions which are most favourable to its development, and what parts to destroy so as to prevent it from continuing its existence in some future period.

Those methods of treating fungus disease which are most commonly practised may be summarised as follows :-

i. The destruction of diseased material, which is best effected by burning the diseased parts or by burying them in pits, with or without the addition of lime, should always be practised; it resolves itself into the diminution of the number of spores by which the fungus reproduces itself. In some cases it is necessary to destroy the whole plant, in others only certain parts of the plant need be destroyed. Diseased material should never be thrown on the manure heap; if this is done a recurrence of the disease is secured.

ii. Parts taken from diseased plants should never be used for propagation. Cuttings, bulbs, seeds and tubers produced by diseased plants, if planted, only serve to perpetuate the disease. The disease caused by Trichosphaeria Sacchari was widely spread by the use of cuttings which were taken from diseased plants.

iii. The application of fungicides may be practised in two ways, either as a preventive measure, i.e., before the disease has appeared, or as a curative measure, i.e., for checking the disease after it has made its appearance. 
The former is by far the more effective measure; it should always be practised when the disease occurs in the neighbourhood or when it has occurred on the plantation in previous years.

The fungicides which are most commonly in use may be enumerated as follows :-

Sulphur, which is applied in the form of "flowers of sulphur" by means of an instrument of similar construction to a "powder-puff."

Liver of Sulphur, applied in the form of a solution of $\mathrm{r} \mathrm{lb}$. in 40 gals. of water by means of a spray.

These two fungicides are in general use for superficial moulds.

Bordeaux Mixture, consisting of quick lime (4 lb.), copper sulphate $(4 \mathrm{lb}$.), and water (5o gals.) The quick lime should be in lumps, so as to ensure its having been recently prepared. The copper sulphate should contain as much as 98 per cent. pure sulphate of copper. The mixture is best prepared as follows:-Into a *wooden vessel, such as a tub, whose capacity is 25 gals., 4 lb. of copper sulphate are dissolved; the solution is effected by suspending the copper sulphate, wrapped in a piece of coarse sack, below the surface of the water by tying it to a pole which is laid across the top of the tub. In another tub, holding 25 gals., $4 \mathrm{lb}$. of quicklime are slacked; the water is added slowly at first and the solution is finally made up to 25 gals. The solutions of copper sulphate and lime are then poured together into a tub whose capacity is 50 gals.; during the process the mixture is stirred, and a final stirring of three minutes duration is made after the solutions have been mixed. The mixture is now tested with the blade of a knife or with any other piece of iron; if a red deposition of metallic copper is formed on the surface of the iron, more lime must be added. The mixture must be fresh when it is used and should always be strained immediately before it is transferred to the spraying apparatus. The spraying machine should have a fine nozzle; it is essential that in spraying a cloud of the mixture should be produced which is capable of remaining suspended in the air for a time before it finally settles on the plant. The nozzles recommended by the Board of Agriculture (England) are "Vermorel," which has several modifications, "Mistry" and "Mistry Junior," of American make. Bordeaux mixture is in general use for some diseases of cacao, for some diseases of the cotton plant and for several others. It is the cheapest and most effective fungicide known.

*A metal vessel must not be used. 
Ammoniacal Carbonate of Copper, prepared by mixing I oz. Of carbonate of copper with 5 ozs. of carbonate of ammonia, and dissolving the mixture in I quart of hot water. When thoroughly dissolved, 16 gals. of cold water are added. This solution is a clear liquid and can be used in place of Bordeaux mixture in private or public parks, cunservatories, \&c., where appearances have to be considered.

Quicklime is used for sterilising the soil, especially during attacks from root fungi.

Carbon Bisulphide, has proved itself a very effective soil steriliser. It is being extensively used in Germany and in other parts of Europe at the present time; the difficulties connected with its transport by water over long distances have prevented its use in most of the Colonies; but when these difficulties are overcome it will no doubt be generally used for treatment of fungi which inhabit the soil.

There are other fungicides which are more or less in general use, such as iron sulphate, Condy's fluid (potassium permanganate), formalin and paraffin, while others are used in special cases.

iv. The isolation of a diseased area, which is effected by surrounding that area with a trench six inches wide and of depth varying according to the distance below the surface to which the fungus can spread, is in general use for the treatment of root fungi.

v. A rotation of crops, which consists in grewing for a certain period on the soil one or more crops which are immune to the fungus present in the soil, resolves itself into an attempt to "starve out" the fungus, and, when properly applied, is an effective method for treatment of root diseases.

vi. The sealing of all wounds which are made during pruning or through other causes should always be practised. The wounds are best sealed with a mixture of coal tar and clay made in such proportions as to form a thick paste, and applied by means of a brush. This practice, accompanied by the production of a vigorous growth on the part of the plant, is effective in preventing attacks from wound parasites.

vii. The selection and propagation of immune varieties and the production of resistant varieties by hybridisation constitutes a highly scientific method which has given good results.

In the above the more generai methods which are in use for the treatment of fungus diseases have been enumerated. The work of plant pathologists is continually providing 
fresh measures for the treatment of plant diseases, and many of these have proved to be eminently serviceable in the past ten years. Where special methods of treatment have been recommended for individual cases these will be found along with the diseases which are treated in the other part of this work.

Problems requiring attention. Of the problems which are connected with the plant pathology of the West Indies at the present time, the more important may now be briefly indicated.

The most important question, perhaps, which concerns the subject of mycology in the West Indies at the present time is the life-history of some of the fungi which are parasitic on cacao. The more serious diseases of cacao are caused by Diplodia cacaoicola, Phytophthora omnivora, Nectria Bainii, and Nectria Theobromae (along with Calonectria flavida). Of these only the life-history of Phytophthora omnivora is known, that of the others remains to be completed. In the case of the canker fungus, Nectric Theobromae, Mr. Van Hall considers that the canker of cacao in Surinam is caused by a Spicaria-form, which is capable of giving rise to a Fusariun-form; the same observer regards the Nectria spp. as being saprophytic, i.e., as being incapable of affecting living parts and as being only able to derive their nutriment from parts which have been previously rendered lifeless. Whether this applies to the canker disease in the West Indies or not, it is not possible to say. A conidial form of the nature of a Spicaria may reasonably be assumed to lead up to some more highly developed form, and the occurrence of the Nectria on the dead parts does not necessarily mean that it is a saprophyte; in fact, the perithecia of the Nertria would normally be expected to occur on the dead parts of the plant, after these had been killed by the mycelium in its conidial phase or phases. Mr. A. Howard's investigations on Nectria Theobrome in Grenada show that a form which produces unicellular conidia and a Fusarium-form are found to precede the Nectria on the diseased stem. The form with unicellular conidia was not, however, sufficiently thoroughly described for it to be identified. The work conducted in the Jodrell Laboratory at Kew has shown that the product of the ascospore is a Cephalosporium-form. Finally, the life-history of Nectria theobromicola, a new species which is parasitic on cacao in West Africa, has recently been shown to be made up of a Cephalosporiumform and the Nectria, The conidial form has been shown to be capable of infecting the stem of the plant and of 
passing into the Nectria, the ascigerous stage. From these observations it would appear to be reasonable to assume that the life-history of the canker fungus of cacao may resolve itself into a Cephalosporium-Fusarium-Nectria lifehistory; but this must be regarded as being little more than mere speculation in the present state of our knowledge. At any rate it represents a line of investigation which may be followed.

No less than the canker fungus does the die-back fungus, Diplodua cacaoicola, require further investigation. This fungus occurs almost wherever the plant is cultivated, but it causes more damage to the plant in the West Indies than in any other country. At present it is regarded by several authors as being synonymous with no less than four other species, viz., Botryodiplodia Theobromae, Patouillard, Macrophoma vestita, Prilleux and Delacroix, Lasiodiplodia nigra, Appel and Laubert, and Botryodiplodia elastica, Petch, the fungus finally resolving itself into Lasiodiplodia Theobromae, Griffon and Maublanc. It will no doubt be generally accepted that the present Diplodia cacaoicola only represents a stage in the lifehistory of an ascigerous fungus. Recent investigations of the fungus at Kew have shown that from the stroma in which the perithecia of Diplodia are embedded a Fusarium-form is produced when the perithecia are in a young condition and before they become erumpent. There is, however, at present no indication of an ascigerous stage. A knowledge of the life-history of this and of the canker fungus may considerably alter the methods which are now practised in treatment of the two diseases.

The question of the identity of Thielaviopsis ethaceticus, "pineapple fungus of sugar cane," as a definite unit or as a stage in the life-history of Trichospharia Sacchari is an interesting problem which should lend itself readily to investigation.

A careful investigation of the crops which are used in rotation with sugar cane is a problem of great importance. At present it would appear to be probable that some of the crops which are used for this purpose are not entirely immune to attacks from Marasmizus Sacchari.

Finally, the different capacities for resisting fungus disease and adverse climatic conditions possessed by the different varieties of the cotton plant is worthy of mention. Some improvement may be expected from the selection of the existing varieties and from the production of new varieties by hybridisation. 



\section{PHYCOMYCETES.}

MuCORACE⿺.

RHIZOPUS NIGRICANS, EHR.

(Soft Rot of Sweet Potato).

A disease of the tubers of the sweet potato has been reported to be caused by this fungus in New Jersey.

The disease is sometimes met with in the field, but is much more frequent among stored potatoes. When attacked, the potatoes become soft and are worthless. In the storehouse the disease spreads rapidly from infected to healthy tubers.

The fungus effects an entrance at a wound on the tuber and develops especially after the tuber has been stored. It makes its appearance on the diseased parts in the form of a black mould.

The following remedial measures have been recommended :-

The storing of the tubers in a well-ventilated room at a termperature of $70^{\circ}$ or more.

Careful examination at repeated intervals for any soft potatoes and their immediate removal from the storehouse.

Diagnosis:-Sporangiferous hyphæ erect, in tascicles of 3-IO, springing from stoloniferous hyphæe which give off rhizoids at corresponding points; sporangia globose, blackisholive, granular, IOO-300 microns diamr. ; columella hemispherical ; spores broadly elliptical or globose, grey, variable in size, 8-I 4 microns diamr. ; zygospore subglobose or tunshaped, I50-200 microns; epispore brown with rounded warts.

HAlSTED : Some fungus diseases of the sweet potato "; New Jersey, Agric. College Exp. Station, Bull. 76, Nov. 28, I 890.

\section{Peronosporacee.}

PHYTOPHTHORA OMNIVORA DE BARY.

(Black Rot of Cacao Pods).

The disease has within recent years become much more general and destructive to pods of the cacao plant in Trinidad. In addition to occurring in the West Indies the 
fungus is known as a parasite on the cacao plant in Ceylon, St. Thomè (West Africa), Samoa, Java, Philippines, Cameroons, and tropical America

When a pod is attacked the shell darkens first at one end, the darkening then spreading over its entire surface. The mycelium permeates and destroys the entire substance of the pericarp of the fruit and often attacks the seeds as well. Attacked fruits are usually rendered valueless.

The conidial form of reproduction of the fungus appears on the surface of the pod as a white mould. Infection probably occurs either at the stigmatic or at the basal end of the pod.

Sexually produced oospores are formed in the tissues of the pod and are capable of enduring a period of rest. They are liberated when the pod decays.

The fungus has not been reported to occur on any plant other than cacao in the West Indies; but in England it is known as a parasite on many different kinds of plants, more especially when they are in the "seedling condition."

All diseased pods should be removed frowl the tree, and these, along with any pods which may have fallen, and husks or shells which may be lying about, should be buried in pits with lime. Spraying with Bordeaux mixture has given very good results, as may be shown from the following :-

In Ceylon, in 1902, ninety-six per cent. of the cacao trees were attacked chiefly by Phytophthora omnivora, and from fourteen to sixty-two per cent. of the pods were diseased; in 1903 the percentage of fungus pods was seven, and in 1904 the percentage was four. The expenditure was more than covered by the increased value of the crop and the discase reduced to a minimum in three years.

Spraying should commence when the pods are just "set" and should be repeated at intervals of three weeks until they are near maturity.

Careful and thorough pruning is of special importance in connection with this disease; it ensures good access of light and air to the lower parts of the plant, and thereby diminishes those conditions of dampness and darkness which are especially favourable for the development of the fungus.

Diaonosis: Hyphæ variously branched, haustoria absent ; conidiophores slender or sparingly unilaterally branched; conidia lemon-shaped, varying in size from 25 by 20 microns to 60 by 40 microns; oospore globose, smooth, yellowishbrown, 20-30 microns diameter.

Hartig and Somerville: Diseases of Trees, p. 38.

MASSEE : Kew Bulletin, p. I, I 899. 
F. C. von Faber: Die Krank. und Parasit. des Kakabaumes, S. I97, I909.

Phytophthora sp. has been reported to cause a blackening and decay of fruits of the Para rubber plant in the Malay States.

RIDLEY: Agric. Bull. of the Straits and Federated Malay States, Vol. V., No. II, I906, p. 397.

\section{PERONOSPORA TRICHOTOMA, MASSEE. \\ (Disease of Colocasia).}

Colocasia esculenta, the tubers of which yield an important food, is known in Barbados as "eddoe," in Jamaica as "coco," and in Trinidad as "tania." The disease was described by Mr. Massee in I 888 , having been reported to occur on "cocos" in Jamaica in that year. The tubers of the plant are the parts affected. When the disease is in its incipient stages the cut surface of a tuber shows a number of bright yellow spots on it, the spots corresponding with the vascular bundles. Later, the spots become brown or blackish and the intermediate portions of the tuber are tinged brown, shewing that the fungus has spread to the ground-tissue separating the vascular bundles. The fungus effects an entrace at a wounded surface, usually where the skin of the tuber has become broken.

Conidia are produced superficially on the tuber, and the oospores are formed in the decaying tissues. Destruction of the diseased tubers (by burying or burning) is recommended; a rotation of crops would also, no doubt, prove to be advantageous in combating the disease.

Diagnosis:-Mycelium thick; haustoria clavate; conidiophores fasciculate, 2-3 times dichotomously divided; conidia small, obovate or subglobose, I2 by io microns, oospore globose, epispore brown with anastomosing ridges, 35-40 microns in diameter.

MASSEE : Journ. Lim. Soc. XXIV., p. 45, I 888.

\section{PERONOSPORA CUBENSIS, BERK. AND CURT.}

(Cucumber Mildew.)

In addition to the cucumber the fungus attacks melon, squash, pumpkin, etc. A delicate white mould forms on 
the under surface of the leaves, and the disease may often prove to be very destructive if it is allowed to go on unchecked.

The disease has been recorded in the United States of America and in Japan.

Spraying with dilute Bordeaux mixture or with a solution of "liver of sulphur" is an effective remedy.

Diagnosis:-Forming very delicate patches on the under surface of the leaf white; conidiophores dichotomously branched, ultimate branches acute, straight, spreading; conidia hyaline, elliptical, 25-32 by i 8-20 microns.

MAssee: Texi Book of Pl. Dis., p. 80, 1907.

Berk. AND CURT. : Joum Limn. Soc. Vol. X., p. 363.

PERONOSPORA HYOSCYAMI, DE BARY.

(Tobacco Mildew).

The fungus is a destructive parasite on cultivated tobacco in Queensland; it has also been reported from California.

Spraying with dilute Bordeaux mixture has been found to be effective in checking the spread of the disease.

Diagnosis:-Forming dirty, greyish-violet tufts on the under surface of the leaf; conidiophores 300-500 microns high, 5-8 times dichotomously branched near the apex, ultimate branches diverging, short and awl-shaped; conidia small, elliptical, ends obtuse, pale dingy-violet, I5-24by I 3 - I 8 microns; oospore unknown.

Massle: Text Book of Pl. Dis. p. 81, 1907.

DE BARY: Am. Nat. Sci. Vol. XX., p. I23.

\section{PYTHIUM PALMIVORUM, BUTLER.}

(Bud Rot of Coconut.)

In addition to the coconut the fungus also causes a disease of paimyra and areca palms in India.

The first symptom is the turning white of a whole leaf situated usually near the centre of the "crown." Next, the unopened leaf in the centre of the "crown" becomes likewise discoloured. Finally, the central shoot rots and the whole crown falls. When a plant is once attacked it rarely recovers.

Butlen: Memoirs of the Pusa Institute, Bull. No.9, I908. 


\section{(Leaf Mould of Sweet Potato.)}

The disease has not been reported to occur in the West Indies, but it is well-known in New Jersey, U.S.A.

Pale spots appear on the leaves; they are followed by brown patches which become darker in colour. On the under side of the leaves a white mould is formed.

Diagnosis:- Spots on both sides, small, dark coloured; acervuli white to pale-coloured, or light yellow, at first covered by the epidermis, then erumpent to free, compact, pulverulent; apical conidium slightly larger than the others, all conidia globose-elliptical or globose-cubical, 15-20 by 1 2-I 3 microns, hyaline; oogonia not seen.

Halsted: New Jersey Agric. College, Expt. Station, Bull. 76, i 890 .

\section{ASCOMYCETES.}

\section{Perisporiacem.}

\section{UNCINULA SPIRALIS, B. \& C. (Powdery Mildew of Grape Vine).}

The disease was first observed in England in the year I 845 , and has since then spread over Europe; it is identical with the well-known mildew of the vine in the United States of America; it has also been recorded in Barbados.

The leaves and grapes are attacked by the fungus; white spots appear on the infected parts and these become later brown and withered. Withering of the infected leaves soon occurs; the grapes, however, continue to grow at places which are not attacked until their coat ruptures, and then they shrivel up.

"Sulphuring" is the method of treatment generally practised. It consists in dusting powdered sulphur over the plant when it is threatened with attack. The sulphur may be dusted by hand, but it is better to use a "puff." The operation should be repeated as frequently as possible.

Diagnosis:-Mycelium arachnoid, amphigenous, often evanescent; perithecia minute, scattered, globose, blackishbrown, appendages 10-20, variable in length, septate, occasionally forked, tips loosely and spirally twisted, basal portion coloured; asci ovate, pedicellate; spores $4-6$, elliptical, ends rounded, $20 \times 8$ - IO microns.

Masse: Text Book of Pl. Dis. p. 92, 1907. 
(Black Heart or Core Rot of Pineapple).

Pineapples in Antigua were reported in $190 \mathrm{I}$ to be suffering from this disease; a similiar disease occurs in Queensland, where the "Smooth Cayenne" variety is said to be frequently attacked.

A diseased fruit, as a rule, ripens unevenly, segments or groups of segments here and there remaining pale-green in colour; if the fruit is cut open black patches can be seen extending from the outside towards the centre, each patch corresponding with a pale-green spot on the surface. Later on, brown patches appear on the surface of the fruit which becomes shrunken in places.

A species of the genus Penicillium occurs in the diseased fruitlets ("eyes"), and this fungus is thought to be the cause of the disease. In Queensland inoculation experiments have shown that the fungus can only effect an entrance at a wounded surface, and punctures produced by insects are considered to provide a point of entrance. In the West Indies two insects commonly occur in the diseased "eyes"; the one is a mealy bug (Dactylopius $s p$.) and the other a mite. It has been suggested that by puncturing the rind these may afford a means of entrance for the fungus. The disease, however, requires careful investigation.

Some species of Penicillium are known to be capable of penetrating into fruits, and, to use the late Professor De Bary's expression, "this they do the more easily, the further the fruits are from the condition of full vital energy." Penicillium italicum and Penicillium olivaceum are the causes of "ripe rot" of the orange, citron, etc., and Penicillium glaucum of the grape.

Stockdale: West Ind. Bull., Vol. VIII., p. i6I.

\section{MELIOLA SPP. \\ (Sooty Mould of Orange).}

The leaves, and sometimes the fruit also, of the orange are frequently covered by a black incrustation which constitutes the mycelium of a fungus belonging to the Perisporiaceæ. The mycelium forms a compact membrane on the upper surface of the leaf, which frequently cracks and peels off in patches. The fungus is not parasitic, but merely follows aphides and other insects 
which secrete "honey-dew." Injury is done to the trees by preventing the leaves from performing their proper functions, and fruit covered by the fungus is frequently rendered unsaleable. The black incrustations occur whereever the orange is cultivated, and are caused by different species of the genus Meliola in different countries.

Messrs. Sivingle and Webber have demonstrated that resin-wash is effective, since it destroys the "honey-dew" secreting insects. It is important that the spraying should be done when the insect is in the larval stage. Fumigagation with hydrocyanic acid gas is also very effective; the treatment should last for about forty-five minutes, and should be done when the temperature is low.

Swingle and Webber: U.S. Dept. Agric., Div. of Veg. Physiol. and Pathol., Bull. No. 8.

Massee: Text-Book of Plant Diseases, p. 100.

\section{DIMEROSPORIUM MANGIFERUM, SACC. (=CAPNODIUM MANGIFERUM, C. \& B.) (Black Blight of Mango.)}

This is a black, incrusting, non-parasitic fungus which forms black patches on both sides of the leaves of mango. The fungus spreads somewhat rapidly, and by forming a coating over the leaves prevents them from carrying out their assimilating functions. It is certain that the fungus follows such insects as secrete "honey-dew." The method of treatment is, therefore, similar to that recommended for the sooty mould of orange (Melzola spp).

Diagnosis:-Mycelium incrusted, effuse, sometimes almost covering the entire surface of the leaf, amphigenous, velvety, intensely black; perithecia globose-pyriform, rounded at apex, mouth absent; asci obovoid, rounded at apex, 48-50 by 30 microns; spores 8 , hyaline, elliptical, slightly constricted at the septum, 12-15 by 5-6 microns.

Massee: Text Book Plant Dis., p. IO3.

CoOke \& Broome: Grev., IV., p. I 17, pl. 63.

\section{Sphaeriace后.}

TRICHOSPHAERIA SACCHARI, MASSEE.

(Rind Fungus of Sugar Cane.)

Attention was first called to the fungus in Trinidad in the year 1893 . At the end of the last century the disease 
was very prevalent in the West Indies, where it almost paralysed the sugar industry for a time; in addition to occurring in the West Indies it has been reported from India, Java, Mauritius and Queensland.

The fungus gains access to the interior of the cane at a wounded surface, such as the broken end of a lateral shoot or leaf base, but more especially through the wounds made by the moth-borer insect (Diatrea saccharalis) and sometimes also the shot-borer (Xyleborus perforans). In the interior of the cane the fungus follows the course of the vascular bundles, and when the disease is in its incipient stages the pulp of the cane shows a number of bright-red longitudinal streaks. Later on, the fungus spreads to the tissue separating the vascular bundles and the whole of the pulp becomes much reddened. Finally, the cane dies and decays.

Black curved tendrils make their appearance on the surface of the diseased cane, oozing out from conceptacles situated below the epidermis and consisting of unicellular, pale-brown conidia. This is known as the Melanconium stage of the fungus. The conidia are for rapid reproduction and can reproduce the fungus without the intervention of any of the other spore-forms.

Later on, lining the cracls and crevices in decaying canes an intensely black, velvety layer is produced consisting of conidia of what is known as the macroconidial stage of the fungus. A microconidial form also occurs and is similar to the macroconidial form, developing from the same hyphæ, but owing its peculiarities probably to light, exposure, etc.

Finally, the ascigerous stage makes its appearance on the dead or more or less decayed canes.

The following measures have proved effective in checking the disease :-

Careful collection and burning of all diseased canes which yield, as a rule, but little juice.

The use of cuttings for replanting which are free from disease.

The sterilisation of cuttings, or "cane plants" as they are often called, by soaking in dilute Bordeaux mixture before planting.

The raising of resistant varieties of sugar cane.

Diagnosis:-Melanconium stage-conidia produced in perithecia formed under the epidermis, unicellular, pale brown, cylindrical, straight or slightly curved, 14-15 by 3.5-4 microns.

Macroconidial stage-conidia produced in chains, origi- 
nating within the ruptured apex of a hypha, terminal conidium globose, $20-25$ microns, the others barrel-shaped, I 8-20 by 12 microns, blackish-brown.

Ascigerous stage-perithecia broadly ovate, blackishbrown, sparsely clothed with long, dark, rigid hairs; asci cylindrical: spores 8, hyaline, continuous, elliptic-oblong, 8-9 by 4 microns ; paraphyses absent.

MASSEE: Annals of Botany, I893, p. 515.

HowARD: Annals of Botany, Vol. XIV, p. 6 I7 (I900), Vol. XVII, p. 373 (1903).

(Pineapple disease).- - Pineapples which have been packed for storing or shipping frequently show signs of fungus disease. The fungus most commonly present is Trichospharia Sacchari. The diseased "pines" are soft and watery, and emit a distinct odour of ethyl acetate. The fungus can only effect an entrance at a wound, such as a bruise on the surface or the cut end of the fruit-stalk.

Stockdale: West Ind Bull., Vol. VIII, p. I63.

\section{LEPTOSPHÆRIA SACCHARI, BREDA DE HAAN. \\ (Ring Spot of Sugar Cane.)}

Occurs in the West Indies, Java and India. The disease commences in the form of small purplish spots on the leaf; these spots increase in size and, as they expand, dry up in the centre. Each spot takes the form of a ring or band which is purple or brownish and outside of which is a yellow area of the leaf. Finally, the spots become large and elongated and frequently run together.

On the surface of the leaf the hyphæ produce 3-4-septate conidia; these have been shown by Mr. Breda de Haan to be capable of infecting living leaves. A second sporeform appears in the form of black dots on the upper surface; the dots are arranged in rows and are visible to the naked eye.

Burning all diseased leaves is effective in checking the spread of the disease.

Diagnosis:--Perithecia I40 microns diamr.; ascospores 3-septate, 20-24 by 5 microns, brownish.

Butlen: Memoirs of Dep. Agric. in India, Vol. I, No. 3.

WAKKER \& WENT: De Ziekten van het Suikerriet op Java, p. 149.

Melanomma henriquesianum, Bres. and Roum. is parasitic on the stem of the cacao plant in the island of 
St. Thomè. The perithecia are large and have a very hard wall; they are dome-shaped and are produced in the bark in large numbers.

Diagnosis:- Perithecia pulvinate or almost hemispherical, apparently superficial, but embedded in the bark, black, carbonaceous, with a very thick wall, about I $\mathrm{mm}$. broad; asci cylindrical, stalked, I20- 140 by I3-I 6 microns; paraphyses filiform; spores ellipsoid, 4-guttulate and 4-septate, slightly constricted at the septa, yellowishbrown, 22-30 by $9-12$ microns.

Bresadola: Revue Mycologique, I89I, p. 68.

\section{EUTYPA ERUMPENS, MASSEE.}

The death of many trees, including cacao, nutmeg, Barbados evergreen (Ficus sp.) and several forest trees, is reported to be caused by this fungus. It occurs in Trinidad, Barbados and Grenada, and is probably a wound parasite.*

When a tree is attacked irregular, black patches make their appearance on the bark; these have a dull, rough surface and consist of the stroma of the fungus in which the perithecia are sunken. The wood of the tree presents a characteristic appearance on examination; a cut surface of the wood shows irregular, black streaks, running more or less longitudinally, and small, black, roundish patches scattered here and there. The black streaks and patches represent the mycelium of the fungus whose growth has become checked. Figures 1 and 2 in plate III show respectively the black patches on the surface of the bark and the appearance of the cut surface of the wood of an infected branch.

Diagnosis:-Stroma broadly effuse, forming patches, innate, then superficial, black inside and outside; perithecia ovoid, often compressed by mutual pressure, $5 \cdot \cdot 8 \mathrm{~mm}$. broad, ostiole papillate; asci cylindric-clavate, with a long stalk, 175-200 by 7-8 microns, eight-spored; spores distichous, cylindrical, subreniform, subacute at both ends, pale olive, I6-I 8 by 5-6 microns.

Bulletin of Agric. Inform., Trinidad, No. 61, 1909.

Eutypa caulivora, Massee, has been reported to occur on the Para rubber plant in the Malay States. It produces a similar effect to the above species, but may be easily distinguished from it by the characters of the spores.

*Species of the genus Eutypa are generally recognised as being wound parasites. 


\section{NECTRIA THEOBROMÆ. MASSEE.}

(Canker of Cacao).

The disease was investigated by Howard, from Grenada in the year 190I; since then it has been met with in Trinidad, Dominica, St. Lucia, and St. Vincent. The first recognisable symptom is the production of a red, gummy liquid which oozes out from the bark of the tree. If the bark is cut off the inner tissues are found to be red in colour, the discolouration extending as far inwards as the young wood. The area affected by the fungus varies; it may take the form of a narrow band which rings the tree, in which case death soon results, or it may spread in different directions without encircling the trunk, in which case death is slower. The branches above the diseased area are cut off and die, those just above that area dying first.

It is important that further work should be done on the life-history of the fungus. Two conidial forms have been reported to precede the Nectria, one is said to be a Fusarium-form, and the other a unicellular form. Observations made at Kew have shown that the ascospores after germination give rise to a Cephalosporium-form, and experiments are bein conducted with a view to investigating the parasitism of this form.

A knowledge of the life-history of the fungus must aid considerably in the recommendation of effective remedial measures. An excision of the cankered part with a sharp knife and careful sealing of all wounds with a mixture of coal tar and clay in the form of a thick paste are advantageous in checking the spread of the disease.

Diagnosis:-Perithecia gregarious or scattered, superficial, ovate, smooth, with orange-coloured hyphæ, red, with a scarcely prominent minute ostiole, $5 \mathrm{~mm}$. high; asci cylindrical, stalked, 8-spored; paraphyses septate, hyaline, with a slightly thickened apex, 3 microns wide; spores obliquely monostıchous, hyaline, ellipsoid, oneseptate, slightly constricted at the septum, $28-30 \times 8-$ IO microns.

Recently a bulletin of the Agricultural Department of Surinam has appeared, in which Mr. Van Hall considers that the canker disease is caused by a Spicaria-form which in artificial media gives rise to a Fusarium-form, and that the ascigerous fungus is saprophytic and has no connection with the disease. It is important to remember that it is of 
common occurrence in the genus Nectria for the ascigerous stage to be produced after the substratum is dead and after the work has been done by the fungus in its conidial phases.

Howard: West. Ind. Bull., Vol. II., p. 200.

Stockdale: West Ind. Bull., Vol. IX., p. I7I.

\section{NECTRIA BAINII, MASSEE.}

\section{(Cacao Pod Disease).}

The fungus was reported to be doing damage to pods of cacao in Trinidad in the year IS9S. Semi-circular blotches make their appearance on the surface of the pod, and these parts become soft and watery. Later on, an orangecoloured mycelium appears, and this becomes studded with bright red perithecia. The perithecia are said to be frequently preceded by Fusarium-like mould which is whitish in appearance; experiments conducted at Kew have led to the conclusion that the ascospores give rise to a Cephalosporium-form after germination. The parasitism of the fungus requires further investigation. It is scarcely possible to suggest remedial measures until the mode of life of the fungus is known; spraying with a suitable fungicide may be efficacious in checking the spread of the disease.

Diagnosis.-Perithecia gregarious, beset by a yellow or orange-coloured mycelium, spherical, red, 300-350 microns diamr.; asci cylindric-clavate, shortly stalked, 8 -spored, $80-90$ by 7-9 microns; spores elliptic-oblong, acute at both ends, uniseptate, hyaline, IO-I 2 by 5 microns.

MASSEe: Kew Bulletin, i 899, p. I.

HART : West Ind. Bull., Vol. I., p. 422.

F. C. VON FABER: Die Krankheiten und Parasiten des Kakaobaumes, p. 216 , 1909.

\section{NECTRIA IPOMOEAE, HALS.}

(Stem Rot of Sweet Potato.)

The sweet potato and the egg-plant have been reported to suffer with this disease in New Jersey. The disease commences near the ground-line and then spreads into the stem and roots. The stem withers and becomes covered with a white mould, the Fusarium condition of the fungus; later on, clusters of flesh-coloured perithecia make their appearance on the diseased stem. 
Diagnosis.-Perithecia in little clusters, conico-globose, papillate, red; asci cylindric-clavate, 8-spored; spores hyaline, cylindric-oblong, I-septate, slightly constricted at the septum.

Halsted: New Jersey Agric. College Expt. Station Report, I89I, p. 28I.

Massee: Text Book of Plant Dis., p. 132.

Nectria sp., causes a canker disease of Hevea brasiliensis (Para rubber) in Ceylon.

Calonectria flavida, Massee, may occur along with Nectria Theobrome on the cankered stem of cacao or without it.

Calonectria gigaspora, Massee, has been described from Trinidad as occurring in the channel made by the mothborer in the stem of the sugar cane.

HART: Trinidad Bulletin, I9OI, p. 335.

MASSEE : Kew Bulletin, Igo6.

Nectria gigantospora, Zimmermann, is recorded as a parasite on the leaves of Ficus elastica in Java.

Diagnosis:-Spots brown; perithecia scattered, round, 300 by 200 microns, red-cinnabar; asci clavate; spores constricted at the septum, truncate at both ends, curved, 50 by 9 microns.

Zimmermann : Bull. Instit. Bot., Buitensorg. r9o I, p. 15.

Nectria striatospora, Zimmermann, was originally described on the bark of the cacao plant in Java ; it is also of common occurence in Ceylon.

Diagnosis :-Perithecia superficial, globose, gregarious, blood-red, with a papillate ostiole, 4 by $3 \mathrm{~mm}$.; asci IOO microns long; spores oblong-ellipsoidal, obtuse at both ends, slightly constricted at the septum, 23 by 9 microns, with the walls longitudinally striated.

Nectria camerunensis, Appel and Strunk, has been reported to occur on fruits of cacao in the Cameroons.

Diagnosis: - Perithecia fleshy, gregarious, yellow, globose-ovoid, $2-\cdot 3 \mathrm{~mm}$. diameter; asci clavate, with a slender stalk, $60-75$ by 12 microns; spores fusoid, acute at both ends, not constricted, distichous or obliquely monostichous, I $2-15$ by $3-4$ microns. 
A pPel and Strunk : Centralblatt f. Bakteriologie Parasitenkunde und Infektionskrankheiten, Abt. II, Bd. XI, I 903.

Nectria Jungeri, P. Henn, found on fruits of cacao in the Cameroons.

Diagnosis:-Perithecia cæspitose, sessile or almost sessile, ovate or mammiform, minutely granulated, 250-300 microns diam.; asci cylindric-clavate, stalked, eight-spored; spores distichous, ellipsoid or oblong, I-septate, not constricted, rounded at both ends, hyaline, 24-28 by 8-IO microns.

Hennings: Fungi camerunenses I; Englers Bot. Jahrb. Bd. XXII, I 897, S. 72.

\section{SPHÆROSTILbE FLAVIDUM, Massee.}

\section{(Coffee Disease of New World.)}

This disease has been reported from Guatemala, New Granada, Costa Rica, Venezuela, Nicaragua, Dutch Guiana and Brazil ; recently the fungus has been found in Dominica. It is known as "spot" or "small pox" in allusion to the spotted appearance of the leaves, young shoots and fruits of infected trees. Scattered circular patches are formed on the leaves and are equally evident on both sides. The leaves become yellowish and fall, and in some cases complete defoliation results. On the shoots the spots are whitish and more or less elongated.

The conidial form of the fungus (Stilbum flavidum) appears on the surface of the spots in the form of yellowish, pin-like structures, each of which bears conidiophores with a single conidum at the tip. All attempts to infect coffee plants with these conidia have failed. The ascigerous stage is developed on the whitish patches of the stem and fruit, but not on the leaves. The fungus is concluded to be reproduced by ascospores only, the conidia being regarded as effete.

Great attention should be paid to the destruction of the diseased stems and fruits, since they contain the spores which serve to carry on the disease. Spraying with Bordeaux mixture or with ammoniacal copper carbonate may prove effective in preventing the disease.

Diagnosis. - Perithecia ovate, densely massed into suborbicular, irregular patches, slightly reddish, verrucose, with a slightly prominent, papillate ostiole; asci cylindrical, 
abruptly truncate above, 8 -spored. Spores hyaline, ellipsoidal, pointed at both ends, uniseptate, 15 by 6-7 microns.

MASSEe: Text Book of Plant, Dis., p. 445.

MASSEe: Keze Bulletin, I909, p. 337.

\section{NECOSMOSPORA VASINFECTA, E. SMith.}

\section{(Vilt Disease of Cotton.)}

The disease was reported in 1900 to be widely distributed through the Southern States of North America, where the "sea island" and "upland" varieties were said to be suffering severely with the pest.

A dwarfed growth and unhealthy appearance of the plants are said to be the first symptoms. Later, the leaves turn yellow and shrivel at their margins. Some plants die at once, while others may last through the season in an unhealthy condition. If the stem of a diseased plant is cut the wood will be found to be stained brown.

The fungus occurs in the soil ; it enters the young roots, penetrates to the tap root and then travels up the stem, blocking the water-conducting tissues.

The progress of the disease is slow, the time taken for the plant to develop symptoms of the disease is said to be at least forty days.

The following method of treatment is recommended by the U.S. Department of Agriculture :-

All diseased plants should be removed and burned.

Spread of the disease should be avoided by not grazing cattle on an infected field and by thoroughly cleaning tools which were used on an infected field before using them on another field.

A rotation of five to six years' duration should be practised.

Diseased plants should be kept out of the manure heap.

Diagnosis:--Perithecia superficial, globose-conical, red; asci cylindrical; spores IO-12 microns diam., continuous, globose or subglobose, brownish; paraphyses present.

The wilt disease of okra is also probably caused by this fungus; and the fungus is described in the United States of America as being the cause of the wilt of water melon and cow pea.

E. F. Smith : Bull. U.S.A. Dept. of Agric, No. I7, p. 45, I 899 .

W. A. Orton: Bull. U.S.A. Dept. of Agric., Division of Vegetable Physiology and Pathology, No. 27, 1900. 


\section{UREDINEA.}

\section{UREDO ARACHIDIS, LAGH. \\ (Ground Nut Rust.)}

The leaves of the ground nut, or pea nut, are sometimes affected with this disease. Small, brownish spots appear on the under surface of attacked leaves.

Destruction of the diseased leaves and spraying with a suitable fungicide are to be recommended.

Diagnosis:-Sori small, scattered, on the under side, surrounded by the ruptured epidermis, brown; uredospore ovoid-round, 24-30 microns diamr. ; epispore yellow.

SACCARDO: Sylloge Fungormm. Vol. XIV, p. 394.

Uredo Kïhniz, Wakker and Went, is parasitic on sugar cane in Java, causing a rust of the leaves.

WaKker AND Went: "De Ziekten van het Suikerriet op Java," p. 144.

\section{UREDO CANNA, WINTER.}

\section{(Canna Rust.)}

The disease was first described from Brazil; more recently it has made its appearance in Trinidad, where it has proved to be a destructive pest to cultivated cannas. Small, orange-coloured spots are formed on the leaves, which become discoloured and die.

The destruction of diseased leaves is to be recommended; spraying with a suitable fungicide should also be effective in checking the spread of the disease.

Diagnosis.-Sori generally hypophyllous, rarely also epiphyllous, either densely scattered over the entire surface or collected in groups, minute, pale yellow, for a long time covered by the epidermis; spores variable in form, yellowish, echinulate, $25-46$ by 16-23 microns.

Massee : Text-Book of Plant Dis., p. 423. Trinidad Bull., Vol. III., p. 86. 


\section{(Cotton Rust.)}

The fungus was first recorded in South America (Ecuador) and has since been seen in the West Indies; it has recently caused considerable damage to cotton in the United States. In the West Indies, however, the disease does not appear to be a dangerous one.

All green parts of the plant are affected by the fungus. On the upper surface of attacked leaves small, purplishbrown, roundish or angular spots appear; they may be scattered or confluent in large groups. The leaves dry up and become brown.

Diagnosis.-Sori formed below the epidermis, then bursting forth; spores ovoid or pyriform, 24-30 by $15-18$ microns; epispore equally thickened, pale yellow, echinulate; paraphyses clavate.

LAGERHEIM : Joumal of Mycology, Vol. VII., p. 48.

LEWTON-Brain : West Ind. Bull., Vol. VI., p. II7.

HEMILEIA VASTATRIX, BERK. AND BROOME. (Coffee Leaf Disease.)

This fungus was responsible for the damage done to the coffee industry of Ceylon from the year 1875 to the year 1885. It is now widely distributed through the coffeegrowing countries of the Old World-- India, China, Malay Peninsula, East Indies, Philippines, Natal and German East Africa.

The disease in its early stages is indicated by the presence of discoloured spots which are more or less circular in shape; these continue to increase in size, become pale yellow and are studded with bright yellow clusters of spores which eventually become orange-coloured. The spores are confined to the under surface of the leaf.

In addition to the leaves the young shoots and even the fruit may become spotted.

All diseased material should be carefully burnt, and it is likely that treatment with Bordeaux mixture would prove effective.

Diagnosis._Pustules orange, then rufous; spores subreniform, attached obliquely at the base, with convex free surface closely warted and with the two lateral surfaces which are in contact smooth, 35-39 by IO-I 4 microns. 
Massee: Text-Book of Pl. Dis., p. 23i.

BERKELEY: Gardener's Chronicle, p. I I57, I869.

MORRIS: "The Coffee Leaf Disease of Ceylon and Southern India."

Hemilein Canthii, Berk. and Broome, which infects Plectronia campanulata, a wild plant in Ceylon, and Hemileia Woodii, Kalchbr. and Cooke, which occurs on a plant allied to coffee in Natal, are very closely allied to Hemileia vastatrix, and are considered by some as being identical with it.

\section{USTILAGINEA. \\ USTILAGO SACCHARI, RABENH. \\ (Sugar Cane Brand).}

In Java this fungus has been reported to do serious damage to the sugar cane. Mr. O. W. Barrett has observed it in Trinidad, where, however, it appeared to be limited to one or two plantations, and the extent of the damage done seemed to be of a less serious nature.

The leaves are the parts affected, and more especially the younger ones which have not yet separated from each other. The whole of these upper leaves is converted into a discoloured, projecting structure. From the upper part of the affected cane, as a rule, no secondary shoots arise, and those which arise from the lower part become infected in their turn. The discoloured whip-like structure at the end of an attacked cane becomes dusty black and contains the spores of the fungus.

Care should be taken to burn all diseased plants as soon as they are attacked. Cuttings should not be taken from diseased plants. Soaking the cuttings in Bordeaux mixture for six hours or more before planting should prove efficacious in diminishing the spread of the disease.

Diagnosis:-Spore-mass black, spores globose or angularly globose, 8-I8 microns diam., olive brown or rufous, epispore thick, smooth.

WAKIER AND WENT: De Ziekten van het Suikerriet op Java, p. 24.

BarRett : Proc. Agric. Soc. of Trinidad and Tobago, No. 252.

Butlen: Memoirs of Dep. Agric. in India, Vol. I, No. 3. 


\section{GRAPHIOLA PHCENICIS, POIT.}

\section{(Date Palm Disease.)}

The fungus was originally described on the date palm in the East and is now known to occur on other palms in all parts of the world.

Small, raised, dark-coloured spots appear on both sides of the leaves. The internal tissues of infected leaves are frequently much damaged.

Diagnosis:-Outer peridium horny, black; inner peridium membranaceous, hyaline; spore-mass yellow; spores globose or elliptical, 3-6 microns diam., with a thick epispore, smooth, hyaline; filaments IO-1 5 microns thick.

Anm. Sci. Nat. Botanique, 1824, p. 473.

\section{HymenomyCetineæ.}

AgariCACE E.

SCHIZOPHYLLUM COMMUNE, FRIES.

(Sugar Cane Agaric).

This fungus is said to be parasitic on stems of cultivated sugar cane in the West Indies. It has also been recorded as a parasite on the mulberry tree.

Diagnosis.-Pileus fan-shaped, very thin, white or grey, downy, often lobed, I-2 inches broad; gills pale-brown with a purple tinge, split portions of edge of gills revolute; spores dingy, $4-6$ by $2-3$ microns.

MAssee : Text-Book of Plant Dis., p. 207.

Prilleux and Delacroix: Bull du Min. de l'Agric., No. 5, Sept., I 893 .

\section{MARASMIUS SEMIUSTUS, BERK. AND CURT.} (Banana Disease.)

Certain of the banana trees in Trinidad and other of the West Indian Islands have been reported to be affected by this fungus. The fungus permeates the tissues of the banana "stem" and attacks the inflorescence as it is 
growing up the centre of the leaf-sheaths which form the so-called "stem." The fructifications of the fungus can frequently be seen growing in immense numbers on the surface. Numerous, minute, whitish sclerotia are produced in the diseased tissues.

Diseased "stems" should not be allowed to lie and rot on the ground; the fungus should be removed from the "stems" as early after its appearance as possible.

Diagnosis. - Pileus $\frac{1}{2}-\mathrm{I}$ inch across, thin, yellowish-brown, eccentric, concave, then plane, glabrous; gills wide apart, thin and dirty white; stem $\frac{1}{2}-\frac{3}{4}$ inch long, thin, with a flattened foot of attachment, glabrous, $2-3 \mathrm{~mm}$. diamr.

Massee : Text-Book of Plant Diseases, p. 206.

Berkeley : Journ. Linn. Soc., Vol. X., I 869.

\section{MARASMIUS SACCHARI, WAKKER.}

(Root Disease of Sugar Cane.)

The disease has caused considerable loss to sugar cane planters in the West Indies, and was especially prominent in Barbados in 1904. When a plant is attacked it shows symptoms resembling those produced by a deficient water supply. The leaves become dry and withered; fewer leaves are produced, and the lower leaves, which normally fall away from the stem and form "trash" on the ground, remain attached. The stools are dwarfed and but loosely fixed in the soil, so as to be easily uprooted. The fungus attacks the roots, the younger roots being short and red at their tips. The proper absorption of water and salts from the soil is checked and the plants, in consequence, show the symptoms described above. The lowest leaf-sheaths can be seen to be matted together by a white mycelium. The fructifications of the fungus appear at the base of the attacked stools; they are white, delicate structures.

The following remedial measures have been recommended by the Imperial Department of Agriculture for the West Indies :-

I. In the case of badly attacked fields the land should be thrown out of cultivation of sugar cane for as long as possible, and other crops not belonging to the grass family should be grown.

2. All "trash" and old cane stumps should be destroyed; trash from an infected field should never be used for mulching young canes. 
3. In cases where the disease breaks out in a healthy field the diseased area should be isolated by surrounding it by a trench a foot deep.

4. Cuttings should be carefully selected and soaked in Bordeaux mixture for at least six hours and then tarred at the cut ends.

Diagnosis:- Gregarious or fasciculate at the base, variable, flesh membranaceous, persistent; pileus white, broadly campanulate, then dingy white and plane or cupshaped, $15 \mathrm{~mm}$. diamr.; gills white, simple or bifurcate; stem central, white, I $5 \mathrm{~mm}$. long, apex tubiform, base villous; spores hyaline, continuous, irregularly oblong, ends attenuated, rounded, I6-20 by 4-5 microns.

LEWTON-BRaIN : West Ind. Bull., vol. VI., p. 34.

WAKKER AND WENT: De Ziêkten van het Suikerriet op Java, p. I94.

Marasmius plicatus is reported to cause a root disease of the sugar cane in Louisiana; the same species, however, occurs along with the sugar cane in Java where it is considered to be harmless.

\section{MARASMIUS EQUICRINIS, MÜLLER. (Horse-Hair Blight of Cacao.)}

The mycelium of the fungus appears like a tuft of horsehair caught in the twigs of the tree. Some of the threads are closely attached to the bark, and the mycelium resernbles that of the "thread blight" in some respects. The fungus is known to occur in the West Indies.

Diagnosis:-White to yellowish, pileus membranaceous, convex, obtuse, I-2 mm. broad; stalk I $\mathrm{cm}$. or more long, bristly, rigid, black, shining, rising from the black, horse-hair-like mycelium; lamellæ few, separated, paler than the pileus.

LEWTON-Brain : West Ind. Bull., Vol. VI., p. 87.

StOckdale : West Ind. Bull., Vol. IX., p. I79.

COOKE: Grevillea, Vol. VIII.

Marasmius sarmentosus, Fr., is the cause of the horsehair blight of the tea plant and of several forest trees in Ceylon.

Marasmius sp.; the root disease of the sweet potato, and also of the Guinea corn, imphee and Indian corn, is thought to be caused by a species of Marasmius. 


\section{POLYSTICTUS HIRSUTUS, FRIES.}

This fungus has been found on limes in Dominica: it is not clear as to whether it is parasitic or not.

Diagnosis.-Pileus suberose-coriaceous, convex-plane, with rigid hairs, homogeneous in colour, but zoned with concentric grooves, white ; spores round, white, becoming slightly dark in colour.

SACCARDO: Sylloge Fungorum, Vol. VI, p. 257.

\section{FOMES SEMITOSTUS, BERK.}

\section{(Root Disease of Para Rubber.)}

The disease occurs in the Federated Malay States and in Ceylon.

The fungus attacks the tap root of the plant, which becomes soft and finally rots. Deprived of its tap root the plant eventually dies; it may, however, continue to live for a time by absorption of food through the side roots.

The mycelium of the fungus occurs as a white covering on the diseased root, or sometimes as a network of white strands. The strands pass upwards and appear above ground at the base of the tree; when old they are of a yellowish colour; they spread through the soil from one plant to another.

The sporophore of the fungus appears as a semi-circular disc at the base of the tree.

Diagnosis.--Perennial, imbricated, woody; pileus dimidiate, about $10 \mathrm{~cm}$. long and $6 \mathrm{~cm}$. broad, at first red-brown with a yellow, swollen edge, then pale yellow-brown with concentric, dark-brown lines, smooth, feebly sulcate, slightly silky with adpressed fibrils; pore surface orange, red-brown when old; pores minute, $06-12 \mathrm{~mm}$. diamr., rather widely separated, stratose, $2 \cdot 5-3 \cdot 5 \mathrm{~mm}$. long; flesh white, woody, with concentric lines of growth curving from the hymenium to the surface sulcæ.

Petch : "Root disease of Hevea brasiliensis"; Circ. and Agric. Journ., Royal Bot. Gdns., Ceylon, Vol. III, No. 17, 1906 .

RIDLEY: Agric. Bull. of the Straits, Vol. III, p. I74. 


\section{(Root Disease of Coconut.)}

Coconut palms in Ceylon have been reported to be suffering with a disease caused by this fungus. The symptoms of the disease appear to vary somewhat according to the situation in which the plants are growing; in drier situations the progress of the disease is more rapid than in well-cultivated, moister places. The outer leaves wither and droop, remaining suspended around the stem, the tree produces no fruit, the younger leaves are very small and yellowish, and, finally, these young leaves wither and the bud decays.

In addition to attacking the coconut palm, the fungus is considered to cause a root disease of Areca catechic in India, and has also been thought to be parasitic on other plants.

It is interesting to note that Diplodia cacroicola, which has been said to cause a root disease of the coconut palm in Trinidad, also occurs in Ceylon on the dead or diseased roots of the same plant, but is not considered to be the cause of the disease. Dr. Butler has also found a species of Botryodiplodia on diseased roots of the coconut in Travancore.

The following treatment has been recommended for the root disease in Ceylon :-

Dead or badly diseased trees should be felled, and the butt end of the stem should be dug out and burnt, together with the lowest 2 or 3 feet of that part of the stem which is above ground. A trench, at least two feet deep, should be dug around the diseased patch, as far away from the diseased trees as possible.

Diagnosis.-Pileus suberose, then woody, flabelliform, sulcate, with a lateral stalk, yellow changing to reddishbrown; pores long, minute, cinnamon coloured.

Petch : Circulars and Agricultural Journal, Royal Botanic Gardens, Ceylon, Vol. IV., No. 24, I9Io.

\section{THELEPHORACEE.}

\section{HYMENOCHÆTE NOXIA, BERK.}

(Bark Fungus of Cacao.)

This species was discovered in Samoa in 1875, where it was reported to occur more especially on the bread fruit tree, Artocarpus incisa; recently it has made its appearance on cacao in West Africa. 
The fungus takes the form of a brown, incrusted mass on the trunk of the tree, and usually near the base. It spreads somewhat rapidly and causes considerable injury to the plant.

Diagnosis.-Broadly effuse, tenacious and subcrustaceous, adnate; hymenium brown, velvety; setulæ cylindricalconical, $40-70$ by $5-7$ microns; spores ellipsoid, 7 by 4 microns.

MASSEE : "Monograph of the Thelephoree"; Joum. Linn. Soc. Bot., Vol. XXVII., p. Io8.

Hymenochate sp., a fungus which attacks cacao, Castilloa, tea, cotton and other plants in Ceylon has been referred to the genus Hymenochate.

CORTICIUM LILACINO-FUSCUM, BERK. AND CURT.

(Pink Disease of Cacao.)

The disease does not appear to be of a serious nature; it has been reported from Dominica and St. Lucia.

Pinkish incrustations appear on the branches of the tree; they are composed of closely packed, adpressed, fungal hyphæ. The hyphæ may penetrate the bark and extend as far inwards as the young wood; when the branches are thus affected, the bark cracks and peels off. The fungus itself appears to do but little damage, since the bark is easily renewed; but it forms places of entrance for other fungi, notably the cacao canker fungus.

The fungus and the bark adhering to it should be removed by means of a sharp knife and the wound should be tarred.

Diagnosis.-Hymenophore broadly effuse, entirely adnate to the substratum, smooth, waxy, with a narrow white margin, lilac-fuscous; spores continuous, hyaline; basidia tetrasporous.

Stockdale: West Ind. Bull., Vol. IX., p. I78.

\section{CORTICIUM JAVANICUM, Zimm.*}

(Bark Disease of Hevea, \&c.)

The disease is known in Ceylon, Java, and Southern India. In Ceylon in addition to occurring on Hevea brasiliensis it is found on tea (up-country), plum (up-country), orange (low-country) and cinchona; in Java it occurs on coffee, ramie, cacao, cinchona, nutmeg, tea, mango, Castilloa elastica and other plants. 
The fungus is at first only superficial and forms a pink incrustation on the bark. Later, the hyphæ of the fungus penetrate the bark and kill it; the dead bark then peels off from the wood. The fungus does not appear to damage the wood directly. The pink incrustation spreads gradually and may extend for a distance of several feet over the stem and the adjacent branches. In some cases, however, where the growth of the fungus is limited, a cankered appearance of the stem is produced.

The remedies suggested are as follows:-

The removal of the fungus and adjacent bark when it is small, i.e., in an early stage, and the sealing of the wound. If the fungus has covered a considerable portion of the bark and rings the branch the whole branch should be removed.

On young trees, from one to two years old, the stems should be cut away below the affected part.

PETCH : "A bark disease of Hevea, tea \&c.," Circulars and Agric. Joum., Royal Botanical Gardens., Ceylon, Vol. IV, No. 21, 1909.

Corticium calcenm, Massee, is said to cause a similar disease in the Federated Malay States.

\section{HYDNACE压.}

\section{IRPEX FLAVUS, KLOTSCH.}

(Root Fungus of Para Rubber.)

In addition to attacking Para rubber in the Straits, the fungus has been recorded on clove trees in Malacca and is known to cause injury to the coffee plant in the East. It has been reported from Java, Ceylon, Queensland and North America.

The Para rubber trees in the Straits which were attacked were in a young condition. An examination showed that the roots were incrusted with a white mycelium and that the collar of the stem was dead. The fungus is said to occupy a limited area of the soil in contrast with the other root fungus of Para rubber (Fomes semitostus) which spreads rapidly and covers a considerable area.

Diagnosis:-Pileus effuse, spongy, soft, yellow; margin reflexed slightly; teeth compressed, seriate.

RIDLEY :-Agric. Bull. of the Straits and Federated Malay States, Vol. V, No. 3, p. 64, I906

*This is regarded by some as being identical with Corticium lilacino-fuscum. 


\section{FUNGI IMPERFECTI.}

\section{SPhaEROPSIDIACEÆ.}

\section{BOTRYODIPLODIA, SP.}

\section{(Root disease of Coconut.)}

The leaves first show signs of the disease. They become wilted and yellow at their tips, and finally dry up, blacken and hang down. Shedding of the affected leaves sometimes results; the leaf base, however, remains attached to the tree. The nuts are shed in all stages, irrespective of size. The stem has a sour smelling, red discolouration which commences at the level of the ground and extends upwards.

The roots, when examined microscopically, are seen to contain a mycelium composed of dark-coloured, septate hyphæ which run between and through the cells. All tissues of the root appear to be attacked.

The disease occurs in Trinidad and in British Guiana, and appears to have been but little investigated. Recently Mr. Hart has reported a disease of the coconut which he considers to be caused by Diplodia cacaoicola; whether the two are identical or not cannot be definitely said.

Stockdale : West Ind. Bull., Vol. IX, p. 363.

\section{DIPLODIA CACAOICOLA, P. HENN.}

\section{(Die-back of Cacao and brown rot of Cacao Pods.)}

The fungus was originally described from the Cameroons in the year I896; since then, it has been reported from the West Indies, Surinam, Ceylon, Java, Samoa, and St. Thome (West Africa). It has a wide area of geographical distribution and represents the most serious fungus pest on cacao in the West Indies.

The fungus attacks both the stem and fruits of the cacao plant. The disease of the stem is known as "die-back," owing to the characteristic dying back of the affected shoots. The younger shoots are usually first affected; later on, the disease spreads to the older branches and sometimes even to the trunk. Occasionally the diseased area on the trunk may be limited, in which case a canker 
is produced. After the branches are dead and even after they have fallen the fungus continues to produce its perithecia, which appear as small, black structures bursting through the bark.

On the pods the disease is known as "brown rot"; it makes its appearance in the form of a discoloured patch at one or other end of the pod or at a wound on its surface. The discoloured area increases in size and extends over the greater part of the surface. Pods may be attacked in nearly all stages of development; young pods, when once affected, seldom mature; older pods, however, which are attacked when near to maturity may be allowed to ripen.

The fungus effects an entrance into the stem only at a wound; in the case of the fruit, however, it would appear that, in addition to entering at a wound, it is also capable of entering the pod either through the basal or stigmatic end.

Diplodia cacaoicola is regarded by some authors as identical with other species; Griffon and Maublanc (1909) consider Botryodiplodia Theobrome, PAT., Macriphoma vestita, Prill. and Del., Lasiodiplodia nigra, Appel and LAUbert, and Diplodia cacaoicola, P. Henn, as being identical; Petch regards Botryodiplodia elastica, to which he has attributed the later stages of a "die-back" disease of Hevea brasiliensis, as indistinguishable from Diplodia cacaoicola; Van Hall considers that the species of Diplodia, Lasiodiplodia and Chatododiplodic occurring on cacao are identical.

The life-history of the fungus is at present incomplete, and it is most important that it should be thoroughly worked out. If we are to be guided by the principle of analogy, then the fungus would be expected to possess a small, perithecial form belonging to the genus Phoma, or to some allied form-genus, possibly one or more conidial forms and an ascigerous form belonging to the Sphariacere.

A knowledge of the life-history may considerably affect the method of treating the disease. At present the remedial measures practised are :-

(i.) Careful cultivation, manuring and pruning, so as to ensure a vigorous growth of the plant. In a recent publication Mr. Van Hall considers that only leafless and unhealthy trees are affected by the fungus.

(ii.) Sealing of all wounds made during pruning and such as may arise from other causes.

(iii.) Removal of diseased branches (these are to be cut off at a distance of at least six inches below the nearest dead end), pods and shells, and their burial in pits with lime. 
Diagnosis:-Perithecia scattered, in the cortex, innate, black; spores ellipsoid-oblong or sub-ovoid, I-septate, obtuse at both ends, loculi I-guttulate, sooty black, I 8-22 by $12-14$ microns.

A. Howard: West Ind. Bull., Vol. II., p. 203.

P. Hennings: Fungi camerunenses I.; Engler Bot. Jahrb., Bd. XXII., S. 72.

F. A. Stockdale: "Fungus Diseases of Cacao"; Imperial Dept. Agric. for the West Indies, Pamphlet Series, 54, 1908.

VAN Hall: Dept. van den Landbouw, Suriname, Bull. 2I, I9O9.

In addition to occurring on the cacao plant the fungus is known to cause a disease of the sugar cane, it is said to grow on Castilloa in the West Indies and to cause a root disease of coconut in Trinidad.

It is evident that an alteration of the generic name can only be satisfactorily effected if a revision of the allied genera Diplodia, Lasiodiplodia and Chatodiplodia is made. At present it is possible to produce specimens of Diplodia cacaoicola which may be classified under Diplodia, Lasiodiplodia, or Chatodiplodia. In the above account of the disease caused by the fungus the old name Diplodia cacaoicola has been preserved in order to avoid confusion.

Lasiodiplodia tubericola, has been reported to cause a disease of fruits of mango in San Domingo.

Lasiodiplodia sp., is described by Mr. O. W. Barrett as being responsible for the greater amount of the damage done to pods of cacao in Trinidad. This is probably identical with Diplodia cacaoicola.

Barrett: Agric. Soc. Proc., 3 rinidad and Tobago, No. 2 SO.

\section{DIPLODIA RAPAX, MASsee.}

(Stem Disease of Para Rubber).

In July, I909, a stem disease of Hevea brasiliensis was reported from the Federated Malay States and was shown to be caused by the above fungus.

The younger shoots are attacked, turn black and eventually die; the disease continues to spread downwards, and the trunk of the tree becomes affected and finally perishes. 
Numerous raised spots make their appearance on the surface of the bark, these split open and expose the black perithecia of the fungus which are embedded in a stroma.

The fungus has also been recently received at Kew from IVest Africa.

Diagnosis. - Perithecia aggregated, 3-7, globose, black, finally erumpent, glabrous, I60-I 80 microns diamr., with a minute ostiole which scarcely reaches the surface of the stroma; spores elliptical, obtuse at both ends, I-septate in the middle, not constricted, fuliginous, $32-35$ by I5-16 microns.

Ridley : "A New Fungus Pest on Para Rubber"; Agric. Bull. of the Straits and Federated Malay States, Vol. VIII., p. 3IO, Igog.

\section{DIPLODIA EPICOCOS, COOKE.}

\section{(Coconut Disease).}

This fungus was originally described on the leaves of the coconut palm in India. Recently a leaf disease of coconut in Trinidad has been attributed to it.

Diagnosis:-Perithecia scattered or almost gregarious, at length superficial or semi-immersed, globose, black; spores elliptical, $\mathrm{I}$-septate, constricted at the septum, brown, 22 by $10-12$ microns.

Diplcdia sp.; a species of Diploaia is said to attack ripe pineapples in the $\mathrm{West}$ Indies. It effects an entrance through the cut end of the fruit stalk, passes up the central vascular core and spreads to the surrounding pulp. The perithecia appear as black dots under the rind.

Stockdale: West ind. Bull., Vol. VIII, p. 163.

Spharonema adiposum, Butler, causes a black rot of sugar cane in Bengal. Dusky red streaks appear in the interior of the cane and a condition of decay of the interior sets in. The surface of the cane shows no signs of disease.

This fungus possesses an endoconidial stage.

Diagnosis:-Mycelium densely woolly, black; fertile hyphæ simple, septate, producing endoconidia; endoconidia of many forms, cylindrical, pyriform or globose, some hyaline or brown and smooth, others fuscous and warted, 9-25 by 4-1 8 microns; perithecia globose, hairy, black, with a subfimbriated mouth; spores hyaline, continuous, acute at both ends, 6.5 by 3.5 microns. 
Butler: Memoirs of the Agric. Dept. in India, Vol. I, No. 3, p. 35 .

Phoma Batata, Ell. and Hals., causes a dry rot of sweet potato in New Jersey. When a root is attacked its upper end becomes dry and wrinkled. Small pimples appear on its surface, these being the perithecia of the fungus.

Diagnosis :-Perithecia black, gregarious, sunken; spores ovoid, hyaline; basidia slender.

Halsted : Nere Jersey Agric. Coll. Exp. Station, Bull. 76, I 890 .

Macrophoma vestita, Prill. and Delacroix, was described as an injurious parasite on the roots of cacao in equatorial South America. It is now considered by several observers to be identical with Diplodia cacaoicola.

Prilleux and Delacroix: Bull. de la Soc. Myc. de France, Vol. X, I894, p. 165.

Phyllosticta bataiticola, Ell. and Mart., causes a leaf blight of sweet potato in New Jersey. White patches appear on the leaves; these become darker in colour and bear the perithecia of the fungus.

Diagnosis :-Perithecia few, minute, black ; spots small, white with a purple margin; spores oblong-ellipsoid, 5 by 2 microns.

Halsted: New Jersey Agric. Coll. Exp. Station. Bull. $76,1890$.

\section{SEPTORIA NICOTIANA, PAT.}

(Frog-Eye Disease of Tobacco.)

The fungus forms brown spots on the leaves of the tobacco plant; the spots are concentrically zoned and later assume a white appearance. The disease has been reported to occur in Jamaica.

Diagnosis:-Spots concentrically zoned, changing from brown to white; perithecia often hypophyllous, 90-I 40 microns diamr.; spores $50-55$ by $2-3$ microns, hyaline, 3-4-septate.

PATOUILlard and Lagerheim: "Champignons de l'équateur," Bull. ae la Soc. Myc. de France, 1892, p. I 36. 
PESTALOZZIA PALMARUM, COOKE.

(Leaf Disease of Coconut).

A leaf disease of the coconut has been reported to be caused by this fungus in Trinidad and in Cuba. The fungus appears to be only a weak parasite. The leaves droop and wither at the tip, yellowish spots appear on them, and these frequently run together. The colour of the spots changes to a greyish-white with a greenish-brown margin. Finally, the internal tissues of the leaves become destroyed. The leaf-area of the plant is reduced and the yield of fruit is consequently poor; the nuts produced are usually small.

Diagnosis.-Erumpent, blackish, gregarious or scattered ; conidia fusiform, I 5 by 5-6 microns, 4-septate, blackish; stalk elongated, hyaline.

STOCKDALE: West Ind. Bull., Vol. VI., p. 3I3; Vol. IX., p. 37 I.

Cooke: Grevillea, Vol. V., p. 102, pl. 86.

\section{PESTALOZZIA GUEPINI, DESM.}

\section{(Leaf Disease of Para Rubber.)}

The fungus has been reported to occur frequently on the leaves of seedlings of Hevea brasiliensis in Ceylon; it appears to do little damage to the leaves, but it kills the seedling when it attacks the stem at the collar. The diseased patch takes the form of a white ring surrounding the stem and bordered by a narrow, red-brown line.

Other fungi which occur on the leaves of seedlings of Hevea brasiliensis are:-

Helminthosporium Hevece, Petch.

Phyllosticta Hevea, Zimm.

Gleosporium Elastica, Cke. and Massee.

The damage done, however, appears to be limited to small areas of the leaf and is but small.

PETCH: Circulars and Agric. Journ., Royal Bot. Gdns., Ceylon, Vol. III., No. 21, 1906.

Pestalozzia fuscescens, Sor., var. Sacchari, Wakker, produces yellow spots changing to a darker colour on leaves of sugar cane in Java.

WAKKER AND WENT: "De Ziekten van het Suzkerriet op Java," p. I62. 


\section{AND DROST.}

\section{(Witches' Broom of Cacao).}

This disease was reported from Surinam in 1898 ; in 1906 it was observed in Demerara.

When a tree is attacked by the fungus hypertrophied shoots are produced in bunches, the whole structure assuming the appearance of a witches' broom. These branches are enlarged, show a tendency to grow vertically and have well-marked longitudinal furrows at their basal end. Finally, the whole structure thus formed dies. The inflorescence is frequently attacked, with the result that a dense mass of flowers is produced owing to the branching of many of the pedicels; the flowers are usually abortive.

The fungus has been shown to be capable of infecting the fruits directly; such fruits as are attacked show a hardening of the shell, swelling of the fruit-stalk and blackening of the infected area. Diseased pods seldom mature.

Diagnosis:-Stromata isolated, forming small masses of a dirty white or sometimes of a rose colour; conidia continuous, hyaline, slightly constricted at the middle, 13-19 by 4-5 microns, usually with a very refringent region in the centre; setæ multiseptate, black or fuscous, 5O-I2O by $3.5-45$ microns.

Hall and Drost : Recuezl des Trav. Bot. Néerl., Soc. Bot. Néerl., Vol. IV., p. 243, 1908.

Massee: Kew Bulletin, No. 5, 1909.

Howard: West ind. Bull., Vol. II., p. 205.

Colletotrichum Cradzuickii, Bancroft, has been recently found on pods of cacao from Jamaica and is considered to be a new species. The pods had been killed when in a young condition, and their shells were rendered exceedingly hard.

Diagnosis :-Acervuli erumpent, yellow at first, becoming later pink in colour; conidiophores hyaline, length at least greater than that of the conidium; conidia hyaline, pinkish in mass, elongated, with a constriction at the middle, I 4- I 7 by 5 microns; setæ straight, rigid, tapering to a point, 2-3-septate, purple, 70-100 microns long by 4-6 microns broad.

Bancroft: West Ind. Bull., Vol. X., No. 5, 1910. 
Colletotrichum incarnatum, Zimm., has been recorded on pods of cacao which were attacked by Phytophthora omnivora.

Diagnosis:-Acervuli subcutaneous at first, then erumpent, ' 15 to $\cdot 2 \mathrm{~mm}$. long; setæ scattered over the whole of the acervulus, cylindrical or inflated at the base, sparingly septate, black-brown, 85 by $4-5$ microns ; conidia ovoid-oblong, hyaline, I4-19 by 5 microns, granulose within, pink in mass.

Zimmermann: Centraib.f. Bakteriologie, Parasitenkunde und Infektionskrank., Abt. II, Bd. VII, I9OI, S. I43.

Colletotrichum Theobroma, Appel and Strunk, described on fruits of cacao from Victoria.

Diagnosis:--Spots black, gregarious, $1-1 \cdot 2 \mathrm{~mm}$. diamr.; acervuli erumpent at margin of the spot; setæ filiform, acute, multiseptate, black-brown, $60-75$ by 3 microns; conidiophores short, thickened at the base, Io microns long; conidia oblong, obtuse at both ends, straight; without guttules, $9-\mathbf{I} 2$ by $3-5$ microns.

Colletotrichum brachytrichum, Delacroix, on leaves of cacao in Trinidad.

Diagnosis. - Spots on upper side, broad, white or greyish, with a brown margin, subcutaneous and then superficial, about I 30 microns broad; setæ few, black-brown, without septa, curved, 40 by 3-5 microns ; conidia hyaline, ovoidcylindrical, attenuated at the base, rounded at the apex, IO-13.5 by 3-3.75 microns; conidiophores short, 4 by 2 microns.

Colletotrichum theobromicolum, Delacroix, also occurring on fruits of cacao in the West Indies.

Diagnosis.-Acervuli scarcely prominent, up to I $\mathrm{mm}$. broad, densely aggregated, rose at first, then yellow; conidia hyaline, finely granular, cylindrical, often slightly attenuated at the base and rounded at the apex, straight or slightly curved, I 5-I 8 by 4-5 microns; conidiophores more slender, hyaline, $35-45$ by $2 \cdot 5-3$ microns; setæ few, black, with a single septum near the base, the inferior cell hyaline and the superior cell dark-brown, 70 by 2.5 microns.

DELACROIX: "Champignons parasites de plantes cultivées dans les regions chaudes"; Bull. de la Soc. Myc. de France, Vol. XXI., p. I9I, 1905. 


\section{(Melon Rust.)}

The fungus was reported to be injurious to melons in the United States in I889; it was said to be very destructive in hot and moist weather. Brown spots appear on the leaves at first; these become darker in colour, and on them the conidiophores of the fungus appear bearing conidia at their tips.

The application of ammoniacal copper sulphate was recommended.

Diagroosis.-Spots almost round, dark-coloured; acervuli whitish, inflating the epidermis in the middle of the spot and becoming finally erumpent ; conidiophores fasciculate, cylindrical, 45-55 microns long, simple; conidia acrogenous, oblong, straight or curved, rounded at both ends, $15-19$ by $3 \frac{1}{2}-5 \frac{1}{2}$ microns, hyaline.

U.S. Dept. Agric. Botanical Divusion, Bulll. 8, I889.

This fungus also occurs on the bean (Phaseolus vulgaris) in Europe.

\section{COLLETOTRICHUM LAGENARIUM, E. \& HALS.}

\section{(Anthracnose of Watermelon.)}

This species has been recorded on the following plants :watermelon, muskmelon, cucumber, pumpkin, and squash.

The disease is well-known in the United States, where the leaves and fruits of the plants arc frequently anthracnosed.

Mr. B. Halsted regards this species as being identical with Colletotrichum lindemuthianum above.

Halsted: New Jersey, Agric. College Expt. Station Reports, I893, p. 347.

\section{COLLETOTRICHUM FALCATUM, WENT.}

(Red Rot of Sugar Cane).

This disease has been reported from Hawaii, West Indies, Bengal, Madras, Java, and Queensland. When a plant is attacked the upper leaves lose colour and begin to droop; the third or fourth leaves from the unopened bud 
are usually the first to be affected in this way. The leaf commences to wither at the tip and the withering extends down the margins; later on, the whole crown of leaves withers and droops. As far as these primary symptoms are concerned the cane may be suffering from excessive drought ; if, however, the cane be split open, it can be seen to be reddened at one or two of the lower internodes. The discolouration appears as red dots or streaks in the vascular bundles; these streaks extend so as to form blotches, and finally the interior of the cane becomes much reddened. Each blotch has usually a white centre compused of dead cells. The reddening extends down into the stool and also towards the top of the cane. The cane becomes light and loses much of its juice; finally, it turns dark in colour and the inside becomes deep-brown and crumbly. When one cane of a stool is affected, infection of the whole stool usually follows. Infection appears to take place from below, i.e., either from the soil or from the parent "cutting."

In some cases the nodes in the middle of the cane may be the first to become infected. In other cases the fungus may attack the roots of the cane or may occur on the leaves.

The spores are produced on the surface of the cane at the nodes or in sunken areas of the internodes. The fungus does not appear to fruit abundantly.

Diagnosis:-Setæ sometimes seriate, sometimes in a pseudo-conceptacle, dagyer-shaped, I09-209 by 4 microns ; conidia sickle-shaped, 25 by 4 microns; conidiophores ovoid, 20 by $\&$ microns, hyaline or fuscous.

Went : Mededeelingen van het Prefstation, West Java, I 893.

Butler : Mem. Agric. Dept. in India. Vol. I, No. 3.

MASsee : "Root Diseases of Sugar Cane," Kerv Bulletin, No. 48, I 893.

\section{COLlETOTRICHUM AGAVES. CAV.}

(Disease of Agave).

A disease of species of Agave is caused by this fungus, and has been reported from Antigua. Spots are formed on the leavcs, which are darker in colour than the adjacent parts and which eventually turn brown or grey. The plants attacked finally die, unless steps are taken to check the disease. 
The spore-bearing pustules of the fungus appear on the diseased area in the form of orange-coloured spots which are frequently arranged in concentric rings. The fungus makes its entrance through the stomata or by means of wounds.

Diagnosis.-Spots circular or elliptical, often becoming confluent, olive, changing to grey or brown; acervuli spherical to oblong, usually breaking through the epidermis in concentric rings and ejecting orange-coloured masses of conidia; setæ acute to blunt, light-brown, 3-5-septate, 1 IO-I 70 by $5-6$ microns; conidia oblong to cylindrical, hyaline, with one or two guttules, 16-3 I by 5-6 microns; conidiophores erect, hyaline, usually simple, 6-7 microns broad, but very variable in length in different acervuli.

G. G. HedGCOCK: Sixteenth Ann. Report, Missouri Botanical Garden, p. 153.

\section{COLLETOTRICHUM GOSSYPII, SOUTHW.}

\section{(Anthracnose of Cotton.)}

The fruits, stem and leaves of the plant are attacked by this fungus, but the most serious damage is done when it affects the fruits, a loss of as much as 50 per cent. of the crop has been recorded in Alabama, U.S.A.

Minute, reddish-brown spots appear on the "bolls"; these spots increase in size and the inner part of each blackens, the margin remaining reddish-brown. Pustules appear in the centre of the spot and give it a grey or pink colour.

Attacked fruits do not mature properly, they usually become dry and die without opening, or they open only slightly at the top.

In some cases the stems of seedling plants are attacked, the fungus affecting that part of the stem which is just above ground, and the plant withers and dies as if it were "damping off." Such leaves as have become in some way weakened are those which are usually attacked.

The careful selection of non-infected seeds for planting and the soaking of seeds in a one per cent. solution of mercuric chloride for one hour have given good results.

Good results should also attend the raising of resistant varieties.

Diagnosis: Sori orbicular, dark-coloured or covered with a pink powder; acervuli erumpent; conidia irregularly oblong, hyaline, flesh-coloured in mass, II-20 by $4.5-5^{\circ} 5$ 
microns; conidiophores colourless, at least longer than the conidium, $\mathrm{I} 2-2 \mathrm{X}$ by 5 microns; setæ single or in tufts, blackish-brown at the base, almost hyaline at the apex, septate.

SOUTHWORTH : Journ. of Mycology, Vol. VI., p. IOO. ATKINSON : Journ. of Mycology, Vol. VI., p. I73.

LewTon-Brain : West Ind. Bull., Vol. IV., p. 265.

\section{COLLETOTRICHUM GLEOSPORIOIDES, PENZ.}

$$
\text { (Leaf spot, wither tip, etc., of Citrus spp.) }
$$

The species of Citrus which are affected by this fungus are the lemon (Citrus limonum), the orange (Citrus aurantium), the lime (Citrus acida), and the pomelo (Citrus Paradisi). The fungus has been reported to occur in Florida, Jamaica, Cuba, South America, Malta, Italy and Australia, and has, therefore, a wide area of geographical distribution.

The disease commences either at the tip or edge of the leaf, more rarely it starts at the mid-rib or at an inner portion. The parts attacked become light green in colour, and the colour changes later to dark brown. The acervuli of the fungus are formed on the diseased parts, and are at first brown in colour, becoming later dark brown or even black. In this form the disease is known as "leaf spot."

From the leaves the disease may spread to the younger shoots. When a shoot is attacked it dies back for a certain distance from the tip, or it may in some cases die back as far as the trunk. In the former instance a bud situated below the dead part usually develops, but if the disease is not treated the second sprout so formed withers also. In this form the disease is known as "wither tip."

"Leaf-spot" and "wither-tip" are characteristic pathological effects caused by the fungus, and are produced when the lemon, orange and pomelo are attacked. In the case of the lime, however, "anthracnose" of the young shoots usually occurs. In it the upper portion of a shoot is cut off and either hangs down or falls away; the effect is similar to that caused by a biting insect.

In the lime the blossoms and young fruit are frequently attacked by the fungus. Older fruits may be attacked, but those which are more than half mature are seldom 
affected. When a fruit is attacked a portion of it is taken out and falls away, just as if it had been bitten by an insect.

In the lemon the mature fruit suffers most. The fungus enters usually at a bruise on the surface. A dark spot is produced, and finally the whole surface of the rind becomes brown. This is known as "lemon spot."

In the orange and pomelo the fruit is apparently not affected by the fungus.

The following methods of treatment are recommended by the United States Bureau of Plant Industry:-...

For lime trees, spray with Bordeaux mixture as often as is thought fit. For "lemon spot," spray with potassium hydrogen sulphide ("liver of sulphur") after the lemons have been picked, or with ammoniacal copper carbonate, 7-Io days before picking.

Careful pruning and good cultivation remove all the weak parts of the plant and are strongly recommended.

Diagnosis.-Acervuli scattered or loosely gregarious, formed under the epidermis and becoming at length erumpent, depressed, blackish ; setæ cylindrical, apex rounded, continuous or sparingly septate, $40-90$ by 5-6 microns, black or dark-coloured ; conidiophores densely fasciculate, cylindrical, rounded at the apex, continuous, I $8-25$ by 4-5 microns ; conidia acrogenous, cylindrical, straight, rounded at both ends, hyaline, with granulose protoplasm, i6-i 8 by 4-6 microns.

Rolfs: U.S. Dept. Agric. Bull., 52, 1904, Bureau of $\mathrm{Pl}$. Indust.

\section{GLEOSPORIUM ALBORUBRUM, PETCH.}

\section{(Die-Back of Para Rubber.)}

This disease of the Para rubber plant was first investigated in Ceylon in the year 1905 ; since then it has sssumed more serious proportions, and in 1909 it was reported to have caused the death of many of the rubber trees in the island.

The disease may well be divided into two parts, the two being really separate diseases. The first disease takes the form of the dying back of the leading shoot of the tree. The fungus appears to attack that shoot at about the middle of its length. The place attacked becomes dark brown, and this discolouration gradually extends over the whole shoot. The brown patch at first is rather soft, but 
later it becomes hard and finally assumes a grey colour. The fungus responsible for this disease is the above species G. alborubrum.

If the dead top shoot is not removed another disease occurs. The dying back extends to the woody stem, and passes down to the root, when the tree is killed. This disease is caused by Botryodiplodia elastica, Petch, which Mr. Petch considers to be identical with Diplodia cacaoicola.

The parasitism of the two fungi, Gleosporium alborubrum and Diplodia cacaoicola (Botryudiplodia elastica) does not seem to have been investigated, but it would appear from the published account of the disease that the Diplodia sp. depended on the previous attack caused by the Gleosporium $s p$. , and accordingly was little more than a saprophyte, or, at best, a poor wound parasite. This is not the case with the die-back disease of the cacao plant; all the stages in the die-back of the cacac plant are caused by Diplodia cacaoicola, and this fungus is believed to be capable of infecting the pods at either the basal or stigmatic end, so that it is a wound parasite on the stem, and does not depend on any other fungus for its existence as such.

PETCH: "Die-Back of Hevea brasiliensis," Circulars and Agric. Journ. of the Royal Botanic Gardens, Ceylon, Vol. IV., No. 23, I9IO.

\section{GLEOSPORIUM AMPELOPHAGUM, SACC.}

\section{(Grape Rot.)}

This fungus is the cause of a serious disease in European vineyards; it has also caused considerable loss to viticulturalists in the United States, and it has been reported to occur in St. Lucia.

The young shoots, leaves and fruits are attacked. On the leaves small, irregularly scattered, greyish spots are produced; sometimes the centre of the spot falls out, leaving a hole. On the young shoots, tendrils and leafstalks the spots are more elongated. The spots on the fruits are circular and larger than those on the leaves. The growth of the fruits is checked, and they finally shrink and dry up.

Dredging with flowers of sulphur, repeating at intervals of ten days, has been recommended; the collecting of diseased leaves and shoots and the removal of diseased fruits should also be practised. 
Diagnosis.-Spots subcircular, often confluent, centre of spots greyish or rosy-primrose ; pustules originating beneath the epidermis, minute, densely gregarious; conidia oblong, ellipsoid or ovate, $5-6$ by $3-5$ microns, biguttulate, hyaline.

Massee : Text-Book of Plant Dis., p. 278.

Gleosporium MUSARUm, Cke. \& Mass.

(Banana Anthracnose).

A disease of ripe bananas was described from Brisbane as being caused by this fungus; it has since then been recorded in the United States, but there is hitherto no mention of its occurring in the West Indies.

Black spots occur on the fruit and these gradually spread over its entire surface, causing rotting to take place. When the spores of the fungus are extruded a roseate tint is imparted to the spots.

Diagnosis:-Pustules innate, erumpent, gregarious, with a rosy tinge; conidia elongated-ellipsoid, ends rounded, continuous, hyaline, IO-I 2 by 4-5 microns, with granular contents.

Massee: Text-Book of Plant Dis., p. 428.

Stoneman : Bot. Guz., Vol. XXVI., p. 69.

\section{SEPTOGLEUM ARACHIDIS, RAC.}

(Leaf Fungus of Ground Nut.)

The fungus causes black spots to appear on the leaves of the ground nut wherever it is cultivated in the Eastern Hemisphere. The disease spreads rapidly and is said to cause much damage in some countries.

Diagnosis:-Spots orbicular, black, with a brownish-black centre, distinctly limited and surrounded by a pale yellow zone, $4-5 \mathrm{~mm}$. broad in most cases, solitary or numerous and occupying the greater part of the leaf's surface; acervuli arranged concentrically, gregarious, grey-black erumpent; conidia elliptic-fusiform, continuous at first, then 2-4 septate, $20-34$ by 9 microns, grey.

PETCH : Circulars and Agricultural Journal, Royal Botanic Gordens, Ceylon, Vol. III., No. 21, Ig06. 


\section{MuCEDINE.E.}

\section{PELLICULARIA KOLEROGA, CoOkE. \\ (Leaf Rot of Coffee).}

The disease was first noticed in Mysore, S. India, where it was known as leaf rot or "Koleroga"; later, Dr. Ernst found it in Venezuela, and more recently it has been observed in Trinidad and Jamaica.

The fungus covers the leaf with a filmy, gelatinous matter; the mycelium is external. The affected leaves turn black, rot at their tips and fall off.

A knowledge of the life-history of this species would be interesting.

The addition of some fungicide, such as sulphur, liver of sulphur, etc., should act as a preventitive.

Diagnosis:-Effuse, greyish-white, covering the whole leaf's surface; conidia globose, hyaline, echinulate, $7 \cdot 5$ microns diameter, inserted laterally, sessile.

Massee: Kere Bulletin, r893, p. 67,

Hart: West Ind. Comm. Circular, Vol. XXIV., p. 5 Io.

\section{RAMULARIA AREOLA, ATK.}

(Areolate Mildew of Cotton.)

The disease was described by Mr. Atkinson from the United States in I 896 . The mildew is confined to areolate portions of the leaves, the spots being limited by the veinlets and presenting a frosted appearance. It seems probable that the fungus can only do damage to the older leaves.

Diagnosis:--Spots on the under side of the leaf, rarely on both, pale at first, then darker in colour, 1-ro mm. broad, irregular, bounded by the veins of the leaf; hyphæ in small fascicles, many-septate, hyaline, $25-75$ by $4 \cdot 5-7$ microns; conidia oblong, $\mathrm{r}-3$ times septate, formed in chains, $14-30$ by 4-5 microns.

LEWTON-BRAIN : West Ind. Bull., Vol. IV., p. 63.

STOCKDale: West Ind. Bull., Vol. VIII., p. I59. 
(Disease of Seedlings of Cacao.)

This fungus developed on the cotyledons of seedlings of cacao from Dominica and Jamaica when the seeds were planted at Kew ; the fungus was shown to have come from the West Indies. The seedlings attacked by the fungus finally died.

Recently the death of seedlings of cacao in West Africa has been reported to be caused by a fungus disease, and the material forwarded to Kew showed that the fungus belonged to the genus Ramulavia; but from the material received it was not possible to determine whether the species was Ramularia necator or not.

Diagnosis:-Sporodochia superficial, broadly effuse, filamentous, white; sterile hyphæ creeping, densely interwoven, septate, hyaline, 7-10 microns wide, slightly swollen here and there; basidia erect, sparsely branched, the ultimate branches attenuate; conidia elliptic-oblong, rounded at either end, 3-septate, scarcely constricted at the septa, 25-28 by 7-9 microns.

MASSEe: Kew Bulletin, I907, pp. 243 and 298.

Ramularia Göldiana, Sacc. has been reported to kill the leaves and twigs of the coffee plant in Brazil.

Diagnosis.-Spots almost circular, with white and reddish zones; hyphæ filiform; conidia cylindrical, borne in chains, hyaline.

SACCARDO: Sylloge Fungorum, Vol. X., p. 554.

Dematiex.

CERCOSPORA NICOTIANÆ, E. \& E.

(Leaf Spot of Tubacco.)

This disease is known in the United States, Sumatra and Ceylon, and is considered in the two former countries to cause much damage to the cultivation of the tobacco plant. In Ceylon the disease is not regarded as being of a serious nature, since practically no attention is paid to the "wrapper leaf" cultivation.

Diagnosis.-Spots amphigenous, pale in colour; hyphæ cæspitose, 75-100 by 4-5 microns, septate; conidia 40-75 by $3-3 \cdot 5$ microns, hyaline, curved, often 6-septate.

PETCH: Circulars and Agricultural Journal, Royal Botanic Gardens, Ceylon, Vol. IV., No. 7, 1907. 


\section{CERCOSPORA COFFEICOLA, B. \& C. (Coffee Leaf Spot.)}

This fungus has been reported to occur on leaves of the coffee plant in Trinidad.

Spraying with an ammoniacal solution of copper carbonate would be effective in preventing the disease; the spraying should commence when the leaves are young and should be repeated at intervals.

Diagnosis:- Spots amphigenous, $2-3 \mathrm{~mm}$. diameter, light-coloured or white in the centre with a reddish-brown margin; hyphæ mostly epiphyllous, tufted on the small tubercular base, 50-75 by 4 microns, 2-3-septate, fuscous, sometimes elongated to IOo or 350 microns, nodulose and toothed above; conidia hyaline, $2-4$-septate, 75 by 3 microns at the thicker end.

Journal of Mycology, Vol. IV., p. 5.

\section{CERCOSPORA PERSONATA, ELLIS.}

(Leaf Spot of Ground Nut.)

This disease has recently occurred in Dominica. Brown, almost circular spots are formed on the under surface of the leaves, about $2-4 \mathrm{~mm}$. in diameter.

Spraying the leaves with an ammoniacal solution of copper carbonate, as in the above disease, is an effective remedy.

Diagnosis:-- Hyphæ densely cæspitose, short, brown, continuous; conidia clavate, pale-brown, 3-septate, 30-50 by 5 microns.

ELLIS : Journal of Mycology, I 885.

CERCOSPORA VAGINÆ, KR.

(Red Spot of Sugar Cane.)

Red spots are produced on the leaf stalk, the spots being confined to this part of the leaf. The disease is known in the West Indies, Java, and India.

Several other species of the genus Cercospora occur on the sugar cane. They are :-

C. longipes, Butler-causing the "brown leaf spot" of Bengal.

C. Sacchari, Breda de Haan-causing the "eye spot" disease of Java.

C. acerosum, D. and H.- "black spot" of Java.

C. Köpkëi, Kr. - " red leaf spot" of Java.

Butler: Memoirs of the Agric. Dept.in India, Vol. I., No.3. 
FUSICLADIUM, SP.

(Black Canker of Hevea brasiliensis.)

This disease has been reported to occur in Java and in the Malay States; at present it is not considered to be of a serious nature.

The cut ends of branches or stems left by pruning are the parts which are first affected. Later, the leaves become dry and yellow and finally fall; the flow of latex is diminished and soon ceases. Usually the plant dies soon after it is attacked.

Bernard: Bull. du Departement de l'Agric. aux Indes Néerl., No. 12, Buitenzorg, 1907.

RIDLEY: Agric. Bull. of the Straits and Federated Malay States, Vol. VIII, No. 10, p. 441, 1908.

\section{CLADOSPORIUM ELEGANS, PENZIG.}

\section{(Disease of Orange).}

In addition to the orange the fungus attacks various species of Citrus. It has proved to be injurious in the Southern States of America and in Cuba, as well as in Southern Europe.

The disease appears as white or cream-coloured spots on the leaves, young twigs and fruits. When the leaves are badly attacked they become curled and are covered with warty protuberances.

Spraying with dilute Bordeaux mixture should be commenced early and repeated at short intervals.

Diagnosis:- Tufts epiphyllous, gregarious, distinct, seated on arid spots ; conidiophores erect, fasciculate, simple, sparingly septate, distinctly sinuous, brown, $160-200$ by $5-6$ microns ; conidia apical and lateral, continuous or i-septate, elliptic-oblong, epispore delicately granulated, pale-brown or yellowish, I 8-2C by 5-6 microns.

Massee : Text Book of Plant Dis., p. 436.

Cooke \& Horn : Bull. 9, Estac. Cent. Agron. de Cuba.

THIELAVIOPSIS ETHACETICUS, WENT.

(Pineapple Disease of Sugar Cane).

The cuttings of the sugar cane are attacked by this fungus in the West Indies, Java and India. The disease 
causes great damage in a dry season, when germination and growth are slow. The fungus effects an entrance at the cut ends of the cutting, as a rule, but it can enter at any wounded surface. The fungus pervades the tissues of the stem; the interior of diseased stems, on examination, is found to contain a black mass of hyphæ and spores, and has an odour of pineapple. The growth of the cutting is checked and the plant dies.

Soaking the cuttings in dilute Bordeaux mixture and tarring the cut ends have proved effective measures in the West Indies.

Diagnosis.-Sterile hyphæe almost hyaline; fertile hyphre simple and septate; conidia of two kinds, the macro-conidia ovate and blackish, the micro-conidia hyaline and cylindrical, originating within the ruptured apex of a hypha. Macro-conidia I6-19 by IO-I2 microns. Micro-conidia IO-I 5 by $3 \cdot 5-5$ microns.

LEWTON-Brain : West Ind. Bull., Vol. VI.

WENT: Archief voor de Java Suikerindustrie, 1893.

Stem-bleeding disease of coconut-is a serious disease occurring in Ceylon. The principal symptom is the exudation of a dark-coloured sap from cracks in the bark. This sap is viscid and forms a thick, dark patch which soon turns black. The effect of the disease varies with the age of the tree; in trees under ten years old the external patch is small and gives no indication of the extent of internal decay; in older trees up to the age of forty years, the trunk is frequently hollowed out; on trees over forty years old the trunk is not materially injured.

The fungus which causes the disease has been shown to be Thielaviopsis ethaceticus.

The treatment recommended in Ceylon is to completely cut out the diseased part and to cover the wounded surface with tar.

Petch : Royal Botanic Gardens, Ceylon, Circular, No. 22, IgIO.

A pineapple disease caused by the same fungus has been reported to occur in Hawaii.

TUBERCULARIEæ.

FUSARIUM LIMONIS, BRIOSI.

(Foot Rot of Orange.)

The disease is of common occurrence both in Florida and in Europe; it has been recently found in Jamaica and 
in Cuba. In Florida the disease is known as "foot rot," and in Italy as "mal-di-gomma." Its presence is indicated by the exudation of masses of gum near the base of the trunk. The diseased patches are small at first and gradually increase in size. The disease spreads to the crown and main roots and in many cases girdles the tree; the bark splits and peels off.

In mild cases a tree may recover, but more commonly it dies in about two years after infection has occurred.

Good drainage is essential for combating the disease. The soil should be removed from the base of the trunk and the diseased patches cut away with a sharp knife, the wound thus made being sealed with a mixture of coal tar and clay. It is of the greatest importance that treatment should be applied as soon as the disease makes its appearance.

Diagnosis.-Sporodochia gregarious, confluent, white ; hyphæ spreading, branched, septate; conidiophores erect or ascending, oppositely or alternately branched; conidia very variable, acrogenous, continuous, or septate at the middle, or 2-3-septate, oblong, or fusiform, slightly curved, attenuated, slightly constricted at the septa, hyaline, $26-27$ by $2 \cdot 4-2 \cdot 8$ microns.

Webber and Swingle: U.S. Dept. Agric., Bull. No. 8, I 896

Massee: Text-Book of Plant Dis., p. 332.

\section{MYCELIA STERILIA.**}

OZONIUM AURICOMUM, MASSEE.

(Root Rot of Cotton.)

Has proved itself a serious enemy to the cotton growers of Texas and of the Southern States of North America. It attacks the roots of the plant, destroying the young rootlets and the external surface of the older roots, especially the tap root. The roots become surrounded with a weft of brown strands of mycelium, and the plant wilts, turns black and dies.

The fungus travels in the soil, spreading in all directions from the point first attacked.

Numerous forest and orchard trees have suffered from root disease caused by Ozonium, but members of the grass

* Including those fungi which possess sterile mycelium only. 
family and of the genus Prumus are immune. The tubers of the swcet potato are susceptible to attacks from the fungus.

Ozonium consists of sterile mycelium belonging in most cases to the genus Coprimus.

The fungus is especially active in waterlogged soils and such as are feebly aerated. A deeper tillage is often advantageous in diminishing attacks from the pest, and a rotation of crops of from two to three years duration, in which members of the grass family are employed, is a good means of keeping the pest in check.

Massee: Text Book of Pl. Dis., p. 346, 1907.

Bull. No. 7, Texas Agric. Exp. Station.

Shear and Miles: U.S.A. Dep. Agric., Bureau of Plant Industry', Bull. No. 102, Part V.

Ozonium sp. has been shown to cause a root disease of Para rubber in Brazil.

\section{SCLEROTIUM SP. \\ (Leaf Blight of Coffee.)}

Has been reported from Porto Rico. The fungus appears to attack the root system first and then to ascend the stem by means of brown or black strands; when these strands reach a leaf they spread and form a cobweb-like structure. The leaf dies, but remains attached to the stem by a thread of mycelium.

The genus Sclerotium was founded a long time ago for fungi which possessed masses of hyphæ, usually of more or less definite form, constituting bodies (sclerotia) which are intended for reproduction. The members of the genus Sclerotium have in many cases resolved themselves into species of the genus Sclerotinia.

Porto Rico Agric. Exp. Station Report, p. 399, I904

\section{APPENDIX.}

A. Diseases due to Physiological Causes.

\section{MOSAIC DISEASE OF COTTON.}

The symptoms of the disease are the withering, blackening and premature death of the leaves of the plant. 
They are produced by a lack of vigour on the part of the plant due to excess of water in the soil, or to the absence of some essential element of plant food from the soil. When a hot period, and a rainy one, succeeds a long drought the progress of the disease becomes very rapid. The leaves may fall or may adhere to the plant until the fruit ripens.

When the plant is thus weakened, fungi, which are incapable of attacking it in a healthy condition, make their appearance on the leaves. The fungi which occur most commonly on these leaves are Spharella gossypina and its conidial form Cercospora gossypina, Macrosporium nigricantium and Alternaria sp.

The treatment for this disease varies according to the circumstances under which it occurs. If the disease is due to an excess of water in the soil, a good drainage is to be recommended. If, however, it is due to the absence of some essential element of plant food from the soil, then that element must be supplied in the form of a manure.

The mosaic disease is well-known in the United States; a similar disease has been recorded in East Africa.

Atkinson: "Diseases of the Cotton Plant," U.S. Dept. Agric. Bull. No. 33, I\$g6.

\section{RED LEAF BLIGHT OF COTTON.}

The foliage of the plant reddens like autumn colouring. This is exceedingly common in healthy cotton towards its maturity. It occurs, however, commonly on the "upland" cotton in the United States when the plant is young. In these districts the soil is poor. The bolls produced are few in number and the leaves are shed early. The disease is due to the absence of potash and nitrogen, and probably phosphoric acid.

The remedies consist in supplying the constituents which are lacking.

Atrinson: "Diseases of the Cotton Plant," U. S. Dept. Agric. Bull. No. 33, 1896.

\section{SHEDDING OF BOLLS.}

This occurs in the case of the cotton plant most frequently in extremes of dry or hot weather, or during a change from the one to the other. It may occur, how- 
ever, under normal climatic conditions, especially if the plants are too thick, or if, as occurs in some varieties, a large amount of fruit is produced in proportion to the leaf surface.

Atkinson: "Diseases of the Cotton Plant," U.S. Dept. Agric. Bull., No. 33, I896.

\section{ANGULAR LEAF, SPOT OF COTTON.}

In this disease definite spots of the leaf present a watery appearance; the spots are bounded by the veinlets of the leaf. Later, the spots become blackish and then brown, and are frequently bordered by a blackish area. The disease was at first thought to be caused by bacteria, but has since then been attributed to physiological causes.

\section{MELANOSE. \\ (Disease of Citrus spp.)}

The disease appears in the form of small, dark-brown spots on the leaves, stems and fruits of various citrus trees in the United States; it has also been found in Montserrat. It has been attributed to physiological causes.

The spots increase in size and may split in the centres. Many of the leaves fall and, in severe attacks, the branches become twisted and contorted, while the fruit is rendered unsaleable.

Swingle and Webber: U. S. Dept. Agric. Bull. 8, Division of Vegetable Physiology and Pathology.

\section{B. Diseases caused by Bacteria.}

There are a few diseases which have been ascribed to bacteria, but none of them can be said to have been thoroughly investigated.

\section{BACILLUS GOSSYPINUS, ATK.}

(Rot of Cotton Bolls.)

This commences as a small, brown area within the boll, usually at a point near the attachment of the boll to the stalk. The rot spreads through the contents of the boll, and the exterior then shows signs of disease. 
Bolls which are attacked when young do not mature; older bolls may have only a small part of the lint affected.

No infection experiments appear to have been conducted, so that the cause of the disease is at present doubtful.

AtKinson: The Cotton Plant, p. 3 Io.

Lewton-Brain. West Ind. Bull., Vol. IV., pp. 265 and 345 .

\section{BLACK BOLL OF COTTON.}

Occurs in Montserrat and in Antigua.

The symptoms may be described as follows :-

The decay of the internal parts of the boll commences near the base, the seeds swell up and the lint is destroyed. The bolls are practically spherical and taper to a sharp point ; they are, as a rule, shed without opening.

A short, non-motile, rod-like bacillus has been found in the diseased bolls, but no experiments have been conducted for the purpose of ascertaining whether this is the cause of the disease or not.

Leivton-Brain: West. Ind. Bull., Vol. VI., p. ilg.

\section{BANANA LEAF BLIGHT.}

This disease was first observed in Jamaica. A browning of the vascular strands first occurs; this is followed by a blackening of the leaf blade and decay of the whole leaf. The new leaves are attacked in turn as soon as they make their exit from the terminal bud.

The disease has been attributed to a bacterium.

Earle: West. Ind. Bull., Vol. IV., p. 6.

\section{BUD ROT OF COCONUT.}

The disease is said to occur in Jamaica, Cuba, British Honduras, Trinidad, and British Guiana.

The yellowing and dropping of the outer leaves, which are closely followed by shedding of the nuts, are the primary symptoms. The whole terminal bud becomes rotten and the plant dies.

There is no evidence to show that this disease is of bacterial origin.

West. Ind. Bull., Vol. VI., p. 307. 


\section{DESCRIPTION OF PLATES.}

\section{PLATE I.}

Phytophtkora ommevora.

FIG. I. A transverse section of a pod of cacao shewing conidiophores emerging at the surface.

Fig. 2. An oospore.

Peronospora trichotoma.

FIG. 3. A branched conidiophore bearing conidia.

Fig. 4. Two conidia more highly magnified.

FIG. 5. An oospore.

FIG. 6. The cut surface of a tuber shewing the black spots which correspond with the positions of the vascular bundles.

Dimerosporium mangiferum.

FIG. 7. A mature perithecium.

FIG. 8. An ascus with spores.

Uncinula spiralis.

FIG. 9. A hypha producing a chain of conidia.

FIG. IO. Two conidia more highly magnified.

FIG. II. A perithecium with appendages.

\section{Plate II.}

Trichospheria Sacchari.

FIG. I. A cane shewing the curved tendrils of the Melanconium stage oozing out from the surface.

FIG. 2. The cut surface of a cane shewing the effect produced by the macroconidial stage.

FIG. 3. Hyphæ producing macroconidia.

FIG. 4. A perithecium.

Fig. 5. An ascus.

Melanomma henriquesianum.

FIG. 6. A piece of bark of cacao shewing perithecia emerging from the surface.

FIG. 7. A longitudinal section shewing an erumpent perithecium containing asci

Fig. 8 An ascus.

FIG. 9. A single spore highly magnified.

\section{PLATE III.}

\section{Eutypa caulivora.}

FIG. I. The stem of Hevea brasiliensis shewing the black, erumpent patches produced by the fungus.

FIG. 2. The cut surface of the wood of the same plant showing the production of irregular, black streaks which is characteristic of species of the genus Eutypa on wood.

Nectria Bainii.

FIG. 4. A perithecium with byssoid stroma.

FIG. 5. An ascus with spores.

Nectria Ipomoea.

FIG. 6. A perithecium.

FIG. 7. An ascus with spores.

Nectria Theobroma.

Fig. 8. Two perithecia.

FIG. 9. An ascus with spores.

FIG. Io. Two spores.

Spharostilbe flavidum

FIG. II. A portion of a leaf of coffee shewing the fertile hyphr of the Stilbum stage.

FIG. I2. Two fertile hyphæ bearing conidia of the Stilb: $m$ stage.

FIG. I3. A perithecium.

FIG. I4. An ascus with spores. 


\section{Plate IV.}

Leptospheria Sacchari.

FIG. I. A portion of a leaf of sugar cane shewing the ring spots produced by the fungus.

FIG. 2. An ascus with spores.

FIG. 3. Two spores more highly magnified.

Ustilago Sacchari.

FIG. 4. The apex of a shoot of sugar cane showing the apical leaves converted into a black, whip-like structure.

FIG. 5. Two spores.

Marasmius Sacchari.

FIG. 6. The base of a cane bearing toadstools of different ages.

FIG. 7. Two spores.

Corticium javanicum.

FIG. \&. Shewing the hymenium of the fungus.

FIG. 9. Two basidiospores.

\section{Plate V.}

Diploria cacaoicola.

FIG. I. The stem of a cacao plant shewing the perithecia of the fungus erumpent in groups through the surface of the bark.

FIG. 2. The Fusarizm-form which appears on the stroma in which the perithecia are embedded.

FIg. 3. Two mature conidia of the Fusarium-form highly magnified.

FIG. 4. A stroma with two perithecia embedded in it.

FIG. 5. Two spores highly magnified.

Pestalozzia Palmarum

FIG. 6A. Two conidia.

FIG. $6 \mathrm{~B}$ A raised spot from which a curved tendril of conidia is oozing out. Ramularia necator.

FIG. 7. Fertile hyphæ bearing conidia.

\section{Plate Ví.}

Colletotrichum luxificum.

FIG. I. Section of a pod shewing an acervulus.

Colletorrichum Cradwickii.

FIG. 2. A pod of cacao shewing the acervuli of the fungus.

FIG. 3. Section of a pod shewing an acervulus.

Colletotrichum falcatum.

FIG 4. Setæ, conidiophores and conidia.

Colletoirichum incarnatum.

FIG. 5. Section of a pod shewing an acervulus.

Hemileia vastatrix.

FIG. 6. Portion of a leaf of coffee shewing a pale-coloured spot with pustules.

FIG. 7. Two conidia viewed from different sides. 


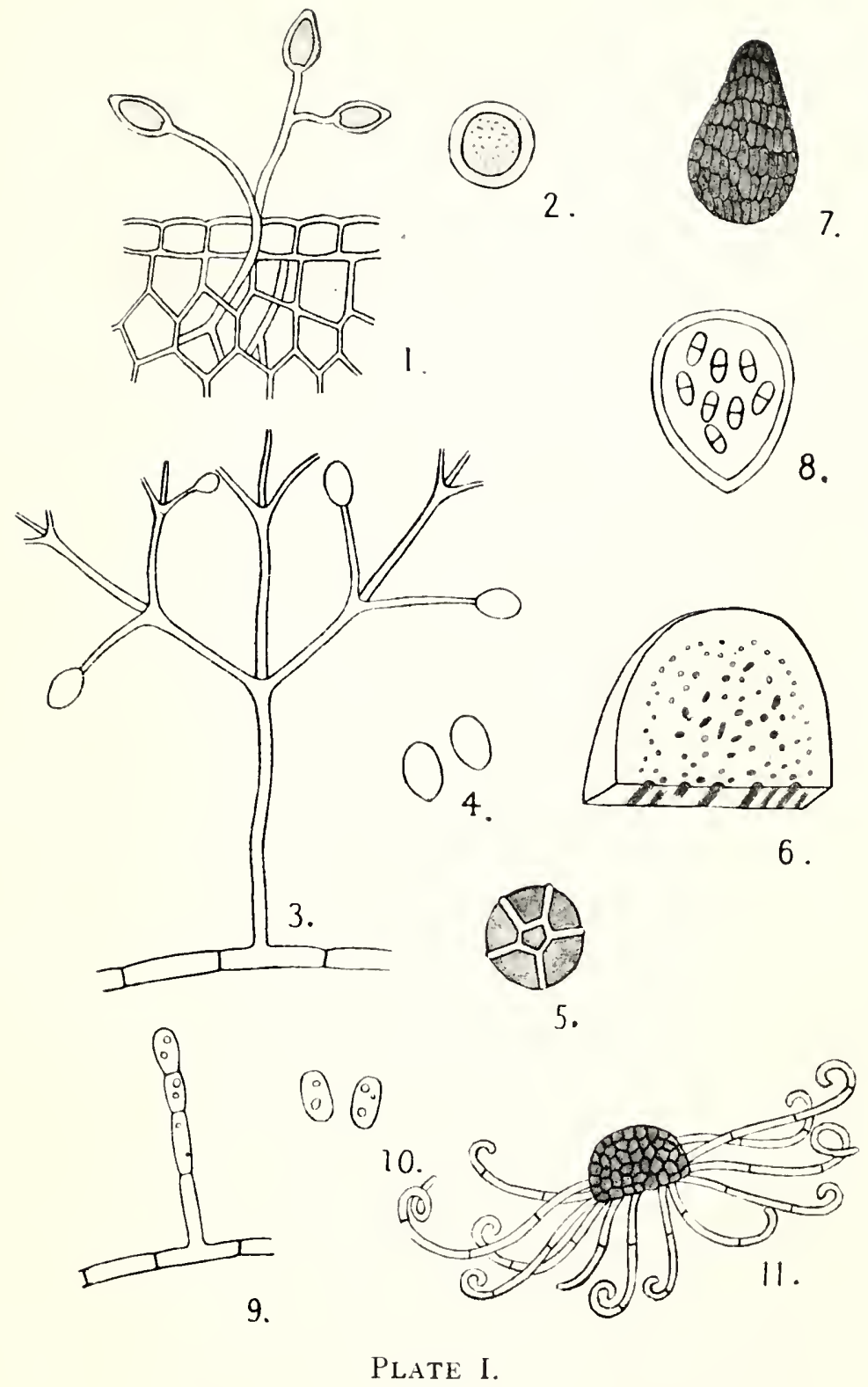





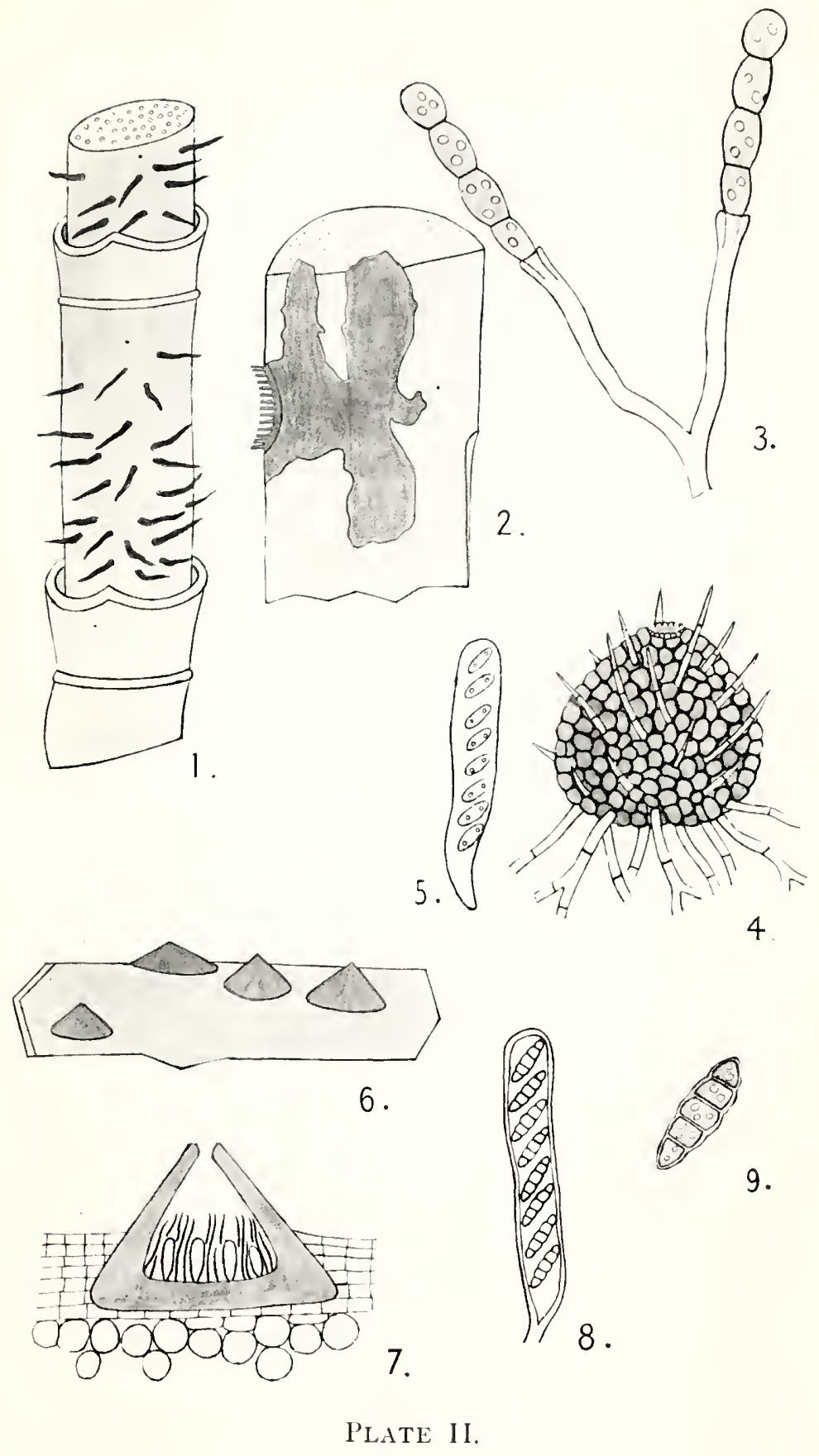




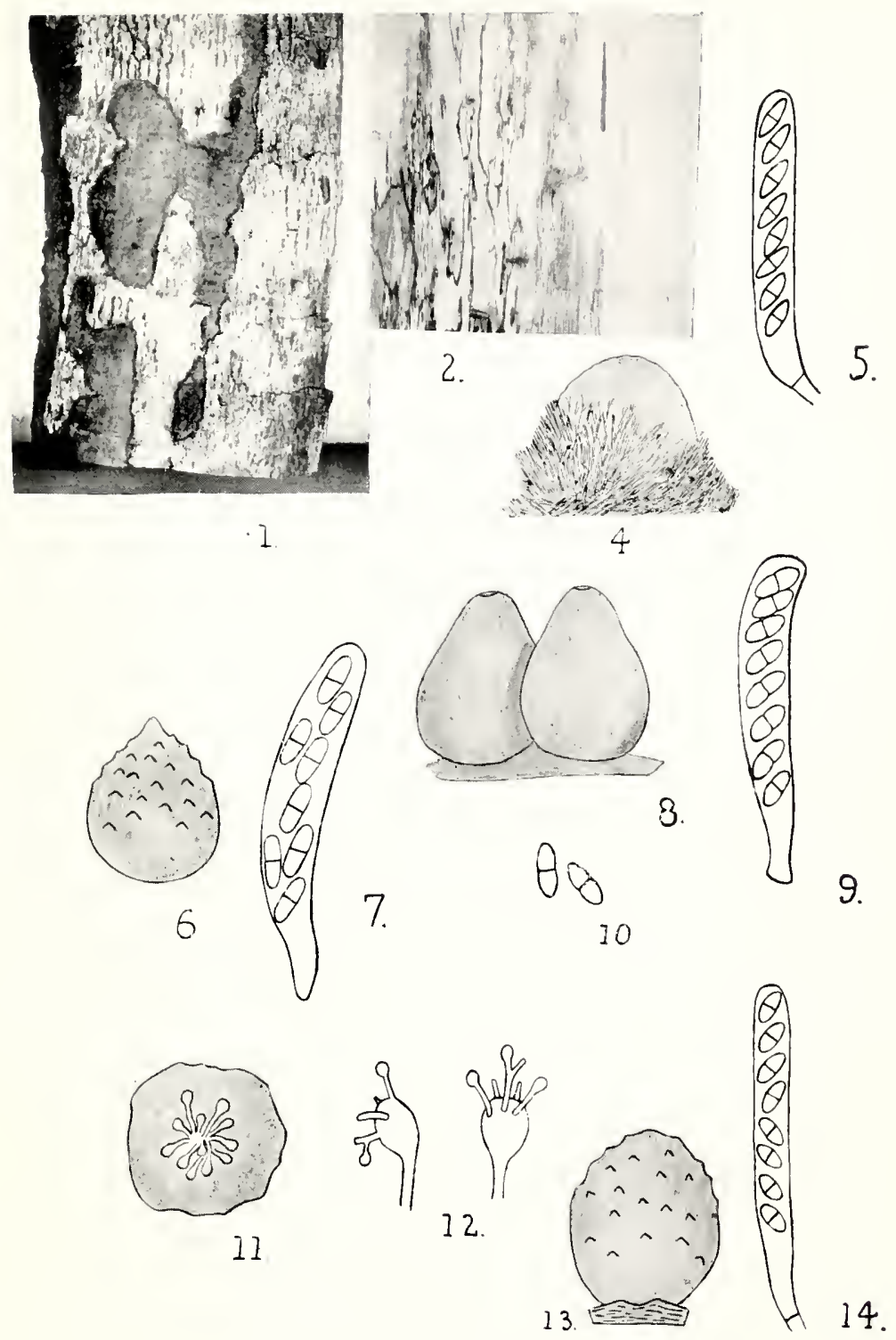

Plate III. 



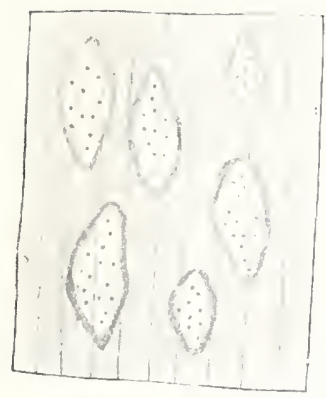

1.
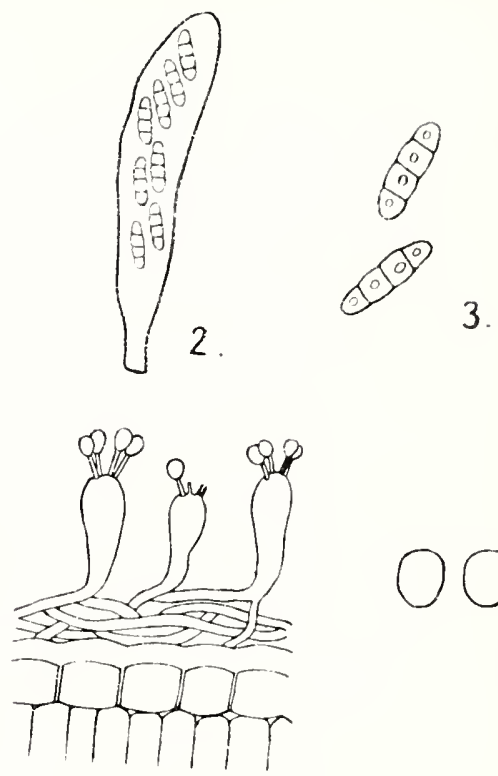

9.

4.
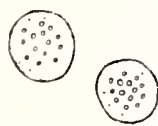

7.

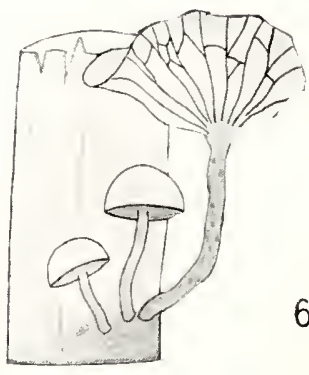

6.

5.

Plate IV. 


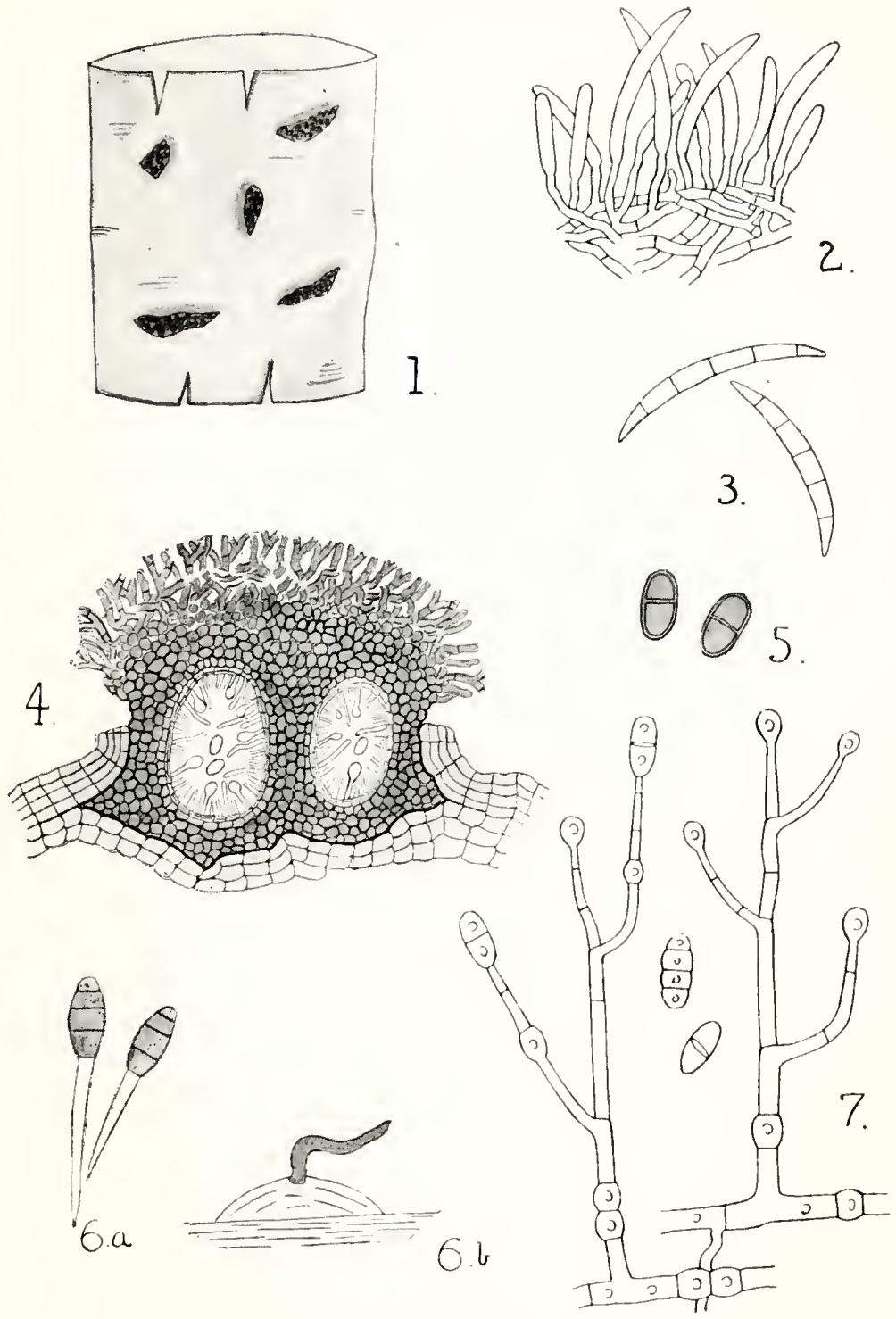

Plate V. 


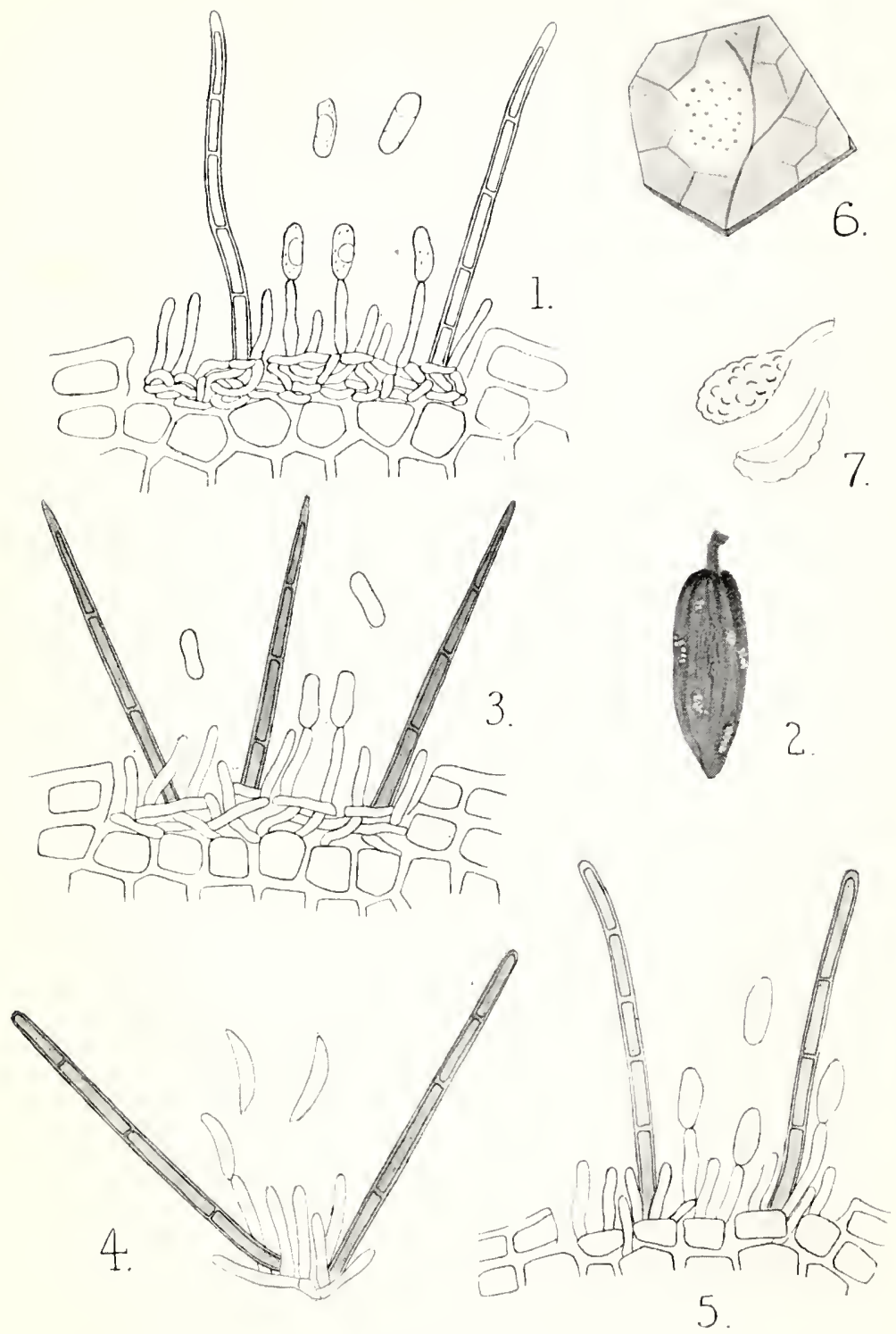

Plate VI. 

Agave, disease of

$\begin{array}{lllllllll}\text { Agave, disease of } & \ldots & \ldots & \ldots & \ldots & \ldots & \ldots & \ldots & 47 \\ \text { Areca Palm, disease of } & \ldots & \ldots & \ldots & \ldots & \ldots & \ldots & \ldots & \text { I6 } \\ \text { Bacillus gossypinus } & \ldots & \ldots & \ldots & \ldots & \ldots & \ldots & \ldots & 6 \text { I } \\ \text { Banana, anthracnose of } & \ldots & \ldots & \ldots & \ldots & \ldots & \ldots & \ldots & 52 \\ \text { Banana, disease of } & \ldots & \ldots & \ldots & \ldots & \ldots & \ldots & \ldots & 3 \text { I } \\ \text { Banana, leaf blight of } & \ldots & \ldots & \ldots & \ldots & \ldots & \ldots & \ldots & 62 \\ \text { Barbados evergreen } & \ldots & \ldots & \ldots & \ldots & \ldots & \ldots & \ldots & 22 \\ \text { Botryodiplodia, sp. } & \ldots & \ldots & \ldots & \ldots & \ldots & \ldots & \ldots & 38 \\ \text { Cacao, bark fungus of } & \ldots & \ldots & \ldots & \ldots & \ldots & \ldots & 21,22,25,35\end{array}$

$\begin{array}{llllllllll}\text { Cacao, black rot of pods of } & \ldots & \ldots & \ldots & \ldots & \ldots & \ldots & 13\end{array}$

$\begin{array}{lllllllll}\text { Cacao, brown rot of pods of } & \ldots & \ldots & \ldots & \ldots & \ldots & \ldots & & 3^{8}\end{array}$

Cacao, canker of

Cacao, die-back of stem of

$\begin{array}{lllllll}\ldots & \ldots & \ldots & \ldots & \ldots & \ldots & 23\end{array}$

Cacao, horse-hair blight of

Cacao, leaf fungus of

Cacao, pod disease of

Cacao, pod fungus of

Cacao, pink disease of .

Cacao, root fungus of

Cacao, seedling disease of

Cacao, witches broom of

Calonectria flavida

Calonectria gigaspora

Canna, rust of

Capnodium mangiferum

Cercospora acerosum

Cercospora coffeicola

Cercospora Köpkëi

Cercospora longipes

Cercospora Nicotiane

Cercospora personata

Cercospora Sacchari

Cercospora Vagine

Citron, ripe rot of

Citrus, melanose of

Cladosporium elegans

Coco, disease of ...

Coconut, bud rot of

$$
\begin{array}{lllllll}
\ldots & \ldots & \ldots & \ldots & \ldots & \ldots & 38 \\
\ldots & \ldots & \ldots & \ldots & \ldots & \ldots & 33 \\
\ldots & \ldots & \ldots & \ldots & \ldots & \ldots & 45
\end{array}
$$

44,45 
Coconut, disease of

Coconut, leaf disease of

Coconut, root disease of

$\begin{array}{llllllllll}\text { Coconut, stem bleeding } & \ldots & \ldots & \ldots & \ldots & \ldots & \ldots & \ldots & 57\end{array}$

$\begin{array}{llllllllll}\text { Coffee, leaf blight of } & \ldots & \ldots & \ldots & \ldots & \ldots & \ldots & \ldots & & 59\end{array}$

$\begin{array}{lllllllllll}\text { Coffee, leaf disease of } & \ldots & \ldots & \ldots & \ldots & \ldots & \ldots & \ldots & & 29\end{array}$

$\begin{array}{lllllllllll}\text { Coffee, leaf } r \text { rot of } & \ldots & \ldots & \ldots & \ldots & \ldots & \ldots & \ldots & & 53\end{array}$

Coffee, leaf spot of $\quad \begin{array}{lllllllll} & \ldots & \ldots & \ldots & \ldots & \ldots & \ldots & \ldots & 55\end{array}$

Coffee, New World disease of $\begin{array}{lllllllll} & \ldots & \ldots & \ldots & \ldots & \ldots & \ldots & 26\end{array}$

$\begin{array}{llllllllll}\text { Colletotrichum Agaves } & \ldots & \ldots & \ldots & \ldots & \ldots & \ldots & \ldots & & 47\end{array}$

$\begin{array}{llllllllll}\text { Colletotrichum brachytrichum } & \ldots & \ldots & \ldots & \ldots & \ldots & \ldots & & 45\end{array}$

$\begin{array}{lllllllll}\text { Colletotrichum Cradwickii } & \ldots & \ldots & \ldots & \ldots & \ldots & \ldots & & 44\end{array}$

$\begin{array}{lllllllll}\text { Colletotrichum falcatum } & \ldots & \ldots & \ldots & \ldots & \ldots & \ldots & 46\end{array}$

$\begin{array}{lllllllll}\text { Colletotrichum gleosporioides } & \ldots & \ldots & \ldots & \ldots & \ldots & \ldots & & 49\end{array}$

$\begin{array}{llllllllll}\text { Colletotrichum Gossypii } & \ldots & \ldots & \ldots & \ldots & \ldots & \ldots & & 4^{*}\end{array}$

$\begin{array}{lllllllll}\text { Colletotrichum incarnatum } & \ldots & \ldots & \ldots & \ldots & \ldots & \ldots & & 45\end{array}$

$\begin{array}{lllllllll}\text { Colletotrichum lagenarium } & \ldots & \ldots & \ldots & \ldots & \ldots & \ldots & 46\end{array}$

$\begin{array}{llllllll}\text { Colletotrichum lindemuthianum } & \ldots & \ldots & \ldots & \ldots & \ldots & 46\end{array}$

$\begin{array}{lllllllll}\text { Colletotrichum luxificum } & \ldots & \ldots & \ldots & \ldots & \ldots & \ldots & & 44\end{array}$

$\begin{array}{lllllllll}\text { Colletotrichum Theobrome } & \ldots & \ldots & \ldots & \ldots & \ldots & \ldots & 45\end{array}$

$\begin{array}{lllllllll}\text { Colletotrichum theobromicolum } & . . & \ldots & \ldots & \ldots & \ldots & \ldots & \ldots & \\ 45\end{array}$

$\begin{array}{lllllllllll}\text { Colocasia, disease of } & \ldots & \ldots & \ldots & \ldots & \ldots & \ldots & \ldots & & 15\end{array}$

$\begin{array}{llllllllll}\text { Corticium calceum } & \ldots & \ldots & \ldots & \ldots & \ldots & \ldots & \ldots & & 37\end{array}$

$\begin{array}{lllllllllll}\text { Corticium jananicum } & \ldots & \ldots & \ldots & \ldots & \ldots & \ldots & \ldots & & 36\end{array}$

$\begin{array}{lllllllll}\text { Corticium lilacino-fuscum } & \ldots & \ldots & \ldots & \ldots & \ldots & \ldots & & 36\end{array}$

$\begin{array}{lllllllllll}\text { Cotton, anthracnose of } & \ldots & \ldots & \ldots & \ldots & \ldots & \ldots & \ldots & & 48\end{array}$

Cotton, angular leaf spot of $\quad \begin{array}{lllllllll} & \ldots & \ldots & \ldots & \ldots & \ldots & \ldots & 6 \text { I }\end{array}$

$\begin{array}{llllllllll}\text { Cotton, areolate mildew of } & \ldots & \ldots & \ldots & \ldots & \ldots & \ldots & & 53\end{array}$

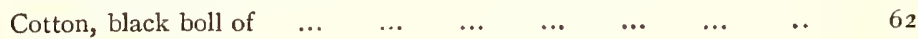

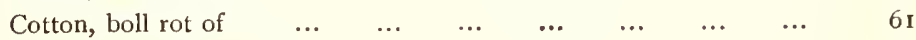

$\begin{array}{llllllllll}\text { Cotton, mosaic disease of } & \ldots & \ldots & \ldots & \ldots & \ldots & \ldots & & 59\end{array}$

$\begin{array}{llllllllll}\text { Cotton, root rot of } & \ldots & \ldots & \ldots & \ldots & \ldots & \ldots & \ldots & & 5^{8}\end{array}$

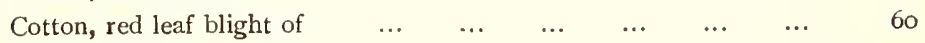

$\begin{array}{lllllllllll}\text { Cotton, rust of } & \ldots & \ldots & \ldots & \ldots & \ldots & \ldots & \ldots & \ldots & 29\end{array}$

Cotton, shedding of bolls of $\quad \begin{array}{lllllllll} & \ldots & \ldots & \ldots & \ldots & \ldots & \ldots & 60\end{array}$

$\begin{array}{lllllllllll}\text { Cotton, wilt of } & . . & \ldots & \ldots & \ldots & \ldots & \ldots & \ldots & \ldots & 27\end{array}$

$\begin{array}{llllllllll}\text { Cow pea, wilt of } & \ldots & \ldots & \ldots & \ldots & \ldots & \ldots & \ldots & 27\end{array}$

$\begin{array}{llllllllll}\text { Cucumber, mildew of } & \ldots & \ldots & \ldots & \ldots & \ldots & \ldots & \ldots & & 15\end{array}$

$\begin{array}{llllllllll}\text { Cystopus Convolvulacearum } & \ldots & \ldots & \ldots & \ldots & \ldots & \ldots & & \text { I7 }\end{array}$

Date palm, disease of $\begin{array}{lllllllllll} & \ldots & \ldots & \ldots & \ldots & \ldots & \ldots & \ldots & & 3 \text { I }\end{array}$

$\begin{array}{lllllllll}\text { Dimerosporium mangiferum } & \ldots & \ldots & \ldots & \ldots & \ldots & \ldots & & \text { I9 }\end{array}$

$\begin{array}{lllllllllll}\text { Diplodia cacaoicola } & \ldots & \ldots & \ldots & \ldots & \ldots & \ldots & \ldots & & 38\end{array}$

$\begin{array}{llllllllll}\text { Diplodia epicocos ... } & \ldots & \ldots & \ldots & \ldots & \ldots & \ldots & \ldots & & 4 \mathbf{I}\end{array}$

$\begin{array}{llllllllllll}\text { Diplodia rapax } & \ldots & \ldots & \ldots & \ldots & \ldots & \ldots & \ldots & \ldots & & 40\end{array}$ 
$\begin{array}{llllllllll}\text { Diplodia sp. } & \ldots & \ldots & \ldots & \ldots & \ldots & \ldots & \ldots & \ldots & 4 \text { I }\end{array}$

$\begin{array}{llllllllll}\text { Eddoe, disease of } & \ldots & \ldots & \ldots & \ldots & \ldots & \ldots & \ldots & \text { I5 }\end{array}$

$\begin{array}{lllllllll}\text { Eutypa caulivora } & \ldots & \ldots & \ldots & \ldots & \ldots & \ldots & \ldots & 22\end{array}$

$\begin{array}{llllllllll}\text { Eutypa erumpens } & \ldots & \ldots & \ldots & \ldots & \ldots & \ldots & \ldots & 22\end{array}$

$\begin{array}{lllllllll}\text { Ficus elastica, disease of } & \ldots & \ldots & \ldots & \ldots & \ldots & \ldots & 25\end{array}$

$\begin{array}{llllllllllll}\text { Fomes lucidus } & \ldots & \ldots & \ldots & \ldots & \ldots & \ldots & \ldots & \ldots & & 35\end{array}$

$\begin{array}{lllllllllll}\text { Fomes semitostus ... } & \ldots & \ldots & \ldots & \ldots & \ldots & \ldots & \ldots & 34\end{array}$

$\begin{array}{llllllllll}\text { Fusarium limonis } & \ldots & \ldots & \ldots & \ldots & \ldots & \ldots & \ldots & 57\end{array}$

$\begin{array}{llllllllll}\text { Fusicladium } \mathrm{sp} . & \ldots & \ldots & \ldots & \ldots & \ldots & \ldots & \ldots & 56\end{array}$

$\begin{array}{lllllllll}\text { Gleosporium alborubrum } & \ldots & \ldots & \ldots & \ldots & \ldots & \ldots & & 50\end{array}$

$\begin{array}{llllllllll}\text { Gleosporium ampelophagum } & \ldots & \ldots & \ldots & \ldots & \ldots & \ldots & 5 \text { I }\end{array}$

$\begin{array}{lllllllllll}\text { Gleosporium Musarum } & \ldots & \ldots & \ldots & \ldots & \ldots & \ldots & \ldots & 52\end{array}$

$\begin{array}{lllllllll}\text { Grape, powdery mildew of } & \ldots & \ldots & \ldots & \ldots & \ldots & \ldots & \text { I7 }\end{array}$

$\begin{array}{llllllllll}\text { Grape, ripe } \operatorname{rot} \text { of } & \ldots & \ldots & \ldots & \ldots & \ldots & \ldots & \ldots & & \text { I8 }\end{array}$

Grape, $\begin{array}{lllllllllll}\text { rot of } & \ldots & \ldots & \ldots & \ldots & \ldots & \ldots & \ldots & \ldots & & \text { 5 I }\end{array}$

$\begin{array}{lllllllllll}\text { Graphiola Phoenicis } & \ldots & \ldots & \ldots & \ldots & \ldots & \ldots & \ldots & & 3 \mathbf{I}\end{array}$

Ground Nut, leaf fungus of $\quad \begin{array}{llllllll} & \ldots & \ldots & \ldots & \ldots & \ldots & \ldots & 52\end{array}$

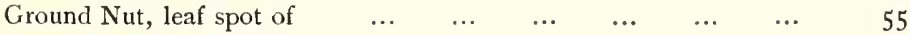

Ground Nut, rust of $\quad \begin{array}{lllllllll} & \ldots & \ldots & \ldots & \ldots & \ldots & \ldots & \ldots & \end{array}$

$\begin{array}{llllllllll}\text { Guinea corn, root disease of } & \ldots & \ldots & \ldots & \ldots & \ldots & \ldots & & 33\end{array}$

$\begin{array}{llllllllll}\text { Hemileia Canthii } & \ldots & \ldots & \ldots & \ldots & \ldots & \ldots & \ldots & & 30\end{array}$

$\begin{array}{lllllllll}\text { Hemileia vastatrix } & \ldots & \ldots & \ldots & \ldots & \ldots & \ldots & \ldots & 29\end{array}$

$\begin{array}{llllllllll}\text { Hemileia Woodii } & \ldots & \ldots & \ldots & \ldots & \ldots & \ldots & \ldots & 30\end{array}$

$\begin{array}{llllllllll}\text { Hymenochaete noxia } & \ldots & \ldots & \ldots & \ldots & \ldots & \ldots & \ldots & & 35\end{array}$

$\begin{array}{lllllllllll}\text { Hymenochaete sp. } & \ldots & \ldots & \ldots & \ldots & \ldots & \ldots & \ldots & 36\end{array}$

Imphee, root disease of $\begin{array}{llllllllll}\ldots & \ldots & \ldots & \ldots & \ldots & \ldots & \ldots & & \end{array}$

Indian corn, root disease of $\quad \begin{array}{lllllllll} & \ldots & \ldots & \ldots & \ldots & \ldots & \ldots & 33\end{array}$

$\begin{array}{lllllllllll}\text { Irpex flavus } & \ldots & \ldots & \ldots & \ldots & \ldots & \ldots & \ldots & \ldots & & 37\end{array}$

$\begin{array}{llllllllll}\text { Lasindiplodia } \mathrm{sp} . & \ldots & \ldots & \ldots & \ldots & \ldots & \ldots & \ldots & 40\end{array}$

$\begin{array}{llllllll}\text { Lasiodiplodia tubericola } & \ldots & \ldots & \ldots & \ldots & \ldots & \ldots & 40\end{array}$

$\begin{array}{lllllllll}\text { Lemon, wither tip, etc. } \ldots & \ldots & \ldots & \ldots & \ldots & \ldots & \ldots & 49\end{array}$

$\begin{array}{llllllllll}\text { Leptosphaeria Sacchari } \ldots & \ldots & \ldots & \ldots & \ldots & \ldots & \ldots & 2 \mathbf{I}\end{array}$

$\begin{array}{llllllllll}\text { Lime, fungus on } \ldots & \ldots & \ldots & \ldots & \ldots & \ldots & \ldots & \ldots & 34\end{array}$

$\begin{array}{llllllllll}\text { Lime, leaf spot, etc. } & \ldots & \ldots & \ldots & \ldots & \ldots & \ldots & \ldots & 49\end{array}$

$\begin{array}{lllllllllll}\text { Macrophoma vestita } & \ldots & \ldots & \ldots & \ldots & \ldots & \ldots & \ldots & 42\end{array}$

$\begin{array}{lllllllll}\text { Mango, black blight of } \ldots & \ldots & \ldots & \ldots & \ldots & \ldots & \ldots & & \text { I9 }\end{array}$

$\begin{array}{lllllllll}\text { Mango, fruit disease of } \ldots & \ldots & \ldots & \ldots & \ldots & \ldots & \ldots & \ldots & 40\end{array}$

$\begin{array}{llllllllll}\text { Marasmius equicrinis } & \ldots & \ldots & \ldots & \ldots & \ldots & \ldots & \ldots & & 33\end{array}$

\begin{tabular}{llllllllll} 
Marasmizes plicatus & $\ldots$ & $\ldots$ & $\ldots$ & $\ldots$ & $\ldots$ & $\ldots$ & $\ldots$ & & \\
\hline 3
\end{tabular}

$\begin{array}{lllllllllll}\text { Marasmius Sacchari } & \ldots & \ldots & \ldots & \ldots & \ldots & \ldots & \ldots & & 32\end{array}$

$\begin{array}{lllllllll}\text { Marasmius Sarmentosus } & \ldots & \ldots & \ldots & \ldots & \ldots & \ldots & & 33\end{array}$

$\begin{array}{llllllllll}\text { Marasmizes Semizustus } & \ldots & \ldots & \ldots & \ldots & \ldots & \ldots & \ldots & 31\end{array}$

$\begin{array}{lllllllllll}\text { Marasmius sp. } & \ldots & \ddots . & \ldots & \ldots & \ldots & \ldots & \ldots & \ldots & \ldots & \end{array}$

$\begin{array}{llllllllll}\text { Meliola } \text { spp. } & \ldots & \ldots & \ldots & \ldots & \ldots & \ldots & \ldots & \ldots & \text { I8 }\end{array}$ 
$\begin{array}{lllllllll}\text { Melanomma henriquesianum } & \ldots & \ldots & \ldots & \ldots & \ldots & \ldots & & 21\end{array}$

Melon, mildew of $\quad \ldots \quad \begin{array}{llllllll} & \ldots & \ldots & \ldots & \ldots & \ldots & \ldots & 15\end{array}$

$\begin{array}{lllllllllll}\text { Melon, rust of } & \ldots & \ldots & \ldots & \ldots & \ldots & \ldots & \ldots & \ldots & 46\end{array}$

$\begin{array}{lllllllll}\text { Necosmospora vasinfecta } \ldots & \ldots & \ldots & \ldots & \ldots & \ldots & \ldots & 27\end{array}$

$\begin{array}{lllllllllll}\text { Nectria Bainii } & \ldots & \ldots & \ldots & \ldots & \ldots & \ldots & \ldots & \ldots & 24\end{array}$

$\begin{array}{llllllllll}\text { Nectria camerunensis } & \ldots & \ldots & \ldots & \ldots & \ldots & \ldots & \ldots & 25\end{array}$

$\begin{array}{llllllllll}\text { Nectria gigantospora } & \ldots & \ldots & \ldots & \ldots & \ldots & \ldots & \ldots & 25\end{array}$

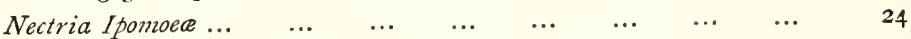

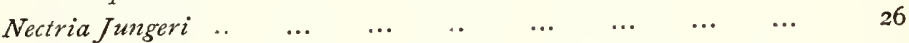

$\begin{array}{llllllllll}\text { Nectria sp. } & \ldots & \ldots & \ldots & \ldots & \ldots & \ldots & \ldots & \ldots & 25\end{array}$

$\begin{array}{llllllllll}\text { Nectria striatospora } & \ldots & \ldots & \ldots & \ldots & \ldots & \ldots & \ldots & 25\end{array}$

$\begin{array}{lllllllll}\text { Nectria Theobrome } & \ldots & \ldots & \ldots & \ldots & \ldots & \ldots & \ldots & 23\end{array}$

$\begin{array}{lllllllll}\text { Nutmeg, stem disease of } & \ldots & \ldots & \ldots & \ldots & . . & \ldots & 22\end{array}$

$\begin{array}{lllllllllll}\text { Okra, wilt of } & \ldots & \ldots & \ldots & \ldots & \ldots & \ldots & \ldots & \ldots & 27\end{array}$

$\begin{array}{llllllllll}\text { Orange, disease of } & \ldots & \ldots & \ldots & \ldots & \ldots & \ldots & \ldots & 56\end{array}$

$\begin{array}{llllllllll}\text { Orange, foot } \operatorname{rot} \text { of } & \ldots & \ldots & \ldots & \ldots & \ldots & \ldots & \ldots & 57\end{array}$

$\begin{array}{lllllllll}\text { Orange, leaf } \mathrm{spot} \text {, etc. } \ldots & \ldots & \ldots & \ldots & \ldots & \ldots & \ldots & 49\end{array}$

$\begin{array}{lllllllll}\text { Orange, ripe } \operatorname{rot} \text { of } & \ldots & \ldots & \ldots & \ldots & \ldots & \ldots & \ldots & 18\end{array}$

$\begin{array}{lllllllll}\text { Orange, sooty mould of } & \ldots & \ldots & \ldots & \ldots & \ldots & \ldots & & \mathbf{1} 8\end{array}$

$\begin{array}{lllllllllll}\text { Ozonium auricomum } & \ldots & \ldots & \ldots & \ldots & \ldots & \ldots & \ldots & & 58\end{array}$

$\begin{array}{lllllllllll}\text { Oronium sp. } & \ldots & \ldots & \ldots & \ldots & \ldots & \ldots & \ldots & \ldots & 58\end{array}$

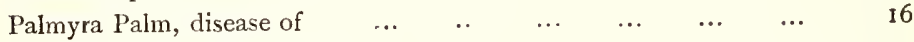

$\begin{array}{llllllll}\text { Para rubber, blackening of fruits } & \ldots & \ldots & \ldots & \ldots & \ldots & 15\end{array}$

Para rubber, black canker of $\begin{array}{llllllll} & \ldots & \ldots & \ldots & \ldots & \ldots & \ldots & 56\end{array}$

Para rubber, bark disease of $\quad \ldots \quad$...

$\begin{array}{lllllllll}\text { Para rubber, canker of } & \ldots & \ldots & \ldots & \ldots & \ldots & \ldots & \ldots & 25\end{array}$

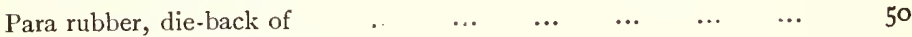

$\begin{array}{lllllllll}\text { Para rubber, leaf diseases of } & \ldots & \ldots & \ldots & \ldots & \ldots & \ldots & 43\end{array}$

$\begin{array}{lllllllll}\text { Para rubber, root disease of } & \ldots & \ldots & \ldots & \ldots & \ldots & \ldots & 34\end{array}$

$\begin{array}{lllllllll}\text { Para rubber, root fungus of } & \ldots & \ldots & \ldots & \ldots & \ldots & \ldots & 37\end{array}$

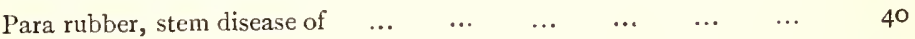

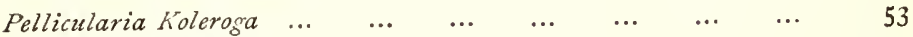

$\begin{array}{llllllllll}\text { Penicillium glaucum } & \ldots & \ldots & \ldots & \ldots & \ldots & \ldots & \ldots & \text { I8 }\end{array}$

$\begin{array}{llllllllll}\text { Penicillium italicum } & \ldots & \ldots & \ldots & \ldots & \ldots & \ldots & \ldots & \text { I8 }\end{array}$

$\begin{array}{lllllllll}\text { Penicillium olivaceum } & \ldots & \ldots & \ldots & \ldots & \ldots & \ldots & & \text { I8 }\end{array}$

$\begin{array}{lllllllllll}\text { Penicillium sp. } & \ldots & \ldots & \ldots & \ldots & \ldots & \ldots & \ldots & \ldots & \ldots & \\ 18\end{array}$

$\begin{array}{llllllllll}\text { Peronospora cubensis } & \ldots & \ldots & \ldots & \ldots & \ldots & \ldots & \ldots & & \mathbf{1 5}\end{array}$

$\begin{array}{lllllllll}\text { Peronospora Hyoscyami... } & \text {.. } & \ldots & \ldots & \ldots & \ldots & \ldots & & \text { I6 }\end{array}$

$\begin{array}{llllllllll}\text { Peronospora trichotoma } & \ldots & \ldots & \ldots & \ldots & \ldots & \ldots & \ldots & & \text { I5 }\end{array}$

$\begin{array}{llllllllll}\text { Pestalozzia fuscescens } & \ldots & \ldots & \ldots & \ldots & \ldots & \ldots & \ldots & & 43\end{array}$

$\begin{array}{llllllllll}\text { Pestalozzia Guepini } & \ldots & \ldots & \ldots & \ldots & \ldots & \ldots & \ldots & & 43\end{array}$

$\begin{array}{llllllllll}\text { Pestalozzia palmarum } & \ldots & \ldots & \ldots & \ldots & \ldots & \ldots & \ldots & \ldots & 43\end{array}$

$\begin{array}{llllllllll}\text { Phyllosticta bataticola } & \ldots & \ldots & \ldots & \ldots & \ldots & \ldots & \ldots & \ldots & 42\end{array}$

$\begin{array}{lllllllllll}\text { Phoma Batate } & \ldots & \ldots & \ldots & \ldots & \ldots & \ldots & \ldots & \ldots & 43\end{array}$ 
$\begin{array}{lllllllllll}\text { Phytophthora omnivora } & \ldots & \ldots & \ldots & \ldots & \ldots & \ldots & \ldots & & \text { I3 }\end{array}$

$\begin{array}{llllllllll}\text { Phytophthora sp. } & \ldots & \ldots & \ldots & \ldots & \ldots & \ldots & \ldots & \text { I5 }\end{array}$

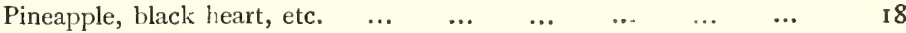

Pineapple, disease of $\quad \begin{array}{lllllllll} & \ldots & \ldots & \ldots & \ldots & \ldots & \ldots & \ldots & 2 \text { I }\end{array}$

Pineapple, ripe rot of $\quad \begin{array}{llllllllll} & \ldots & \ldots & \ldots & \ldots & \ldots & \ldots & \ldots & & 4 \text { I }\end{array}$

$\begin{array}{llllllllll}\text { Plectronia campamelata ... } & \ldots & \ldots & \ldots & \ldots & \ldots & \ldots & & 30\end{array}$

$\begin{array}{llllllllll}\text { Polystictus hirsutus } & \ldots & \ldots & \ldots & \ldots & \ldots & \ldots & \ldots & & 34\end{array}$

$\begin{array}{llllllllll}\text { Pomelo, leaf spot, etc. } & \ldots & \ldots & \ldots & \ldots & \ldots & \ldots & \ldots & \ldots & 49\end{array}$

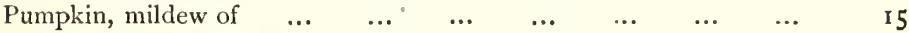

$\begin{array}{llllllllll}\text { Pythium palmivorum } & \ldots & \ldots & \ldots & \ldots & \ldots & \ldots & \ldots & & 16\end{array}$

$\begin{array}{llllllllll}\text { Ramularia areola } & \ldots & \ldots & \ldots & \ldots & \ldots & \ldots & \ldots & & 53\end{array}$

$\begin{array}{llllllllll}\text { Ramularia göldiana } & \ldots & \ldots & \ldots & \ldots & \ldots & \ldots & \ldots & & 54\end{array}$

$\begin{array}{llllllllll}\text { Ramularia necator } & \ldots & \ldots & \ldots & \ldots & \ldots & \ldots & \ldots & & 54\end{array}$

$\begin{array}{llllllllll}\text { Schizophyllum commune } & \ldots & \ldots & \ldots & \ldots & \ldots & \ldots & & 3 \text { I }\end{array}$

$\begin{array}{lllllllllll}\text { Sclerotuim sp. } & \ldots & \ldots & \ldots & \ldots & \ldots & \ldots & \ldots & \ldots & & 59\end{array}$

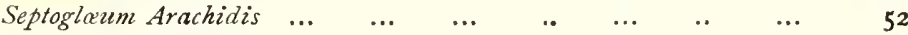

$\begin{array}{llllllllll}\text { Septoria Nicotiane } & \ldots & \ldots & \ldots & \ldots & \ldots & \ldots & \ldots & 42\end{array}$

$\begin{array}{llllllllll}\text { Spheronema Adiposum } & \ldots & \ldots & \ldots & \ldots & \ldots & \ldots & \ldots & 4 \text { I }\end{array}$

$\begin{array}{llllllllll}\text { Spharostilbe flavidum } & \ldots & \ldots & \ldots & \ldots & \ldots & \ldots & \ldots & & 26\end{array}$

$\begin{array}{lllllllll}\text { Squash, mildew of } & \ldots & \ldots & \ldots & \ldots & \ldots & \ldots & \ldots & \text { I5 }\end{array}$

$\begin{array}{llllllllll}\text { Sugar cane, agaric of } & \ldots & \ldots & \ldots & \ldots & \ldots & \ldots & \ldots & 3 \text { I }\end{array}$

Sugar cane, brand of $\quad \begin{array}{lllllllll} & \ldots & \ldots & \ldots & \ldots & \ldots & \ldots & \ldots & \end{array}$

$\begin{array}{lllllllll}\text { Sugar cane, black rot of } & \ldots & \ldots & \ldots & \ldots & \ldots & \ldots & 4 \text { I }\end{array}$

$\begin{array}{llllllll}\text { Sugar cane, pineapple disease of } & \ldots & \ldots & \ldots & \ldots & \ldots & 56\end{array}$

Sugar cane, $\begin{array}{lllllllll}\text { red } r o t \text { of } & \ldots & \ldots & \ldots & \ldots & \ldots & \ldots & \ldots & 46\end{array}$

Sugar cane, red spot of $\begin{array}{lllllllll}\ldots & \ldots & \ldots & \ldots & \ldots & \ldots & \ldots & 55\end{array}$

Sugar cane, root disease of $\quad \begin{array}{lllllllll} & \ldots & \ldots & \ldots & \ldots & \ldots & \ldots & 32\end{array}$

$\begin{array}{lllllllll}\text { Sugar cane, rind fungus of } & \ldots & \ldots & \ldots & \ldots & \ldots & \ldots & & \text { 19 }\end{array}$

$\begin{array}{llllllllll}\text { Sugar cane, } \text { ring spot of } & \ldots & \ldots & \ldots & \ldots & \ldots & \ldots & 2 \text { I }\end{array}$

$\begin{array}{llllllllll}\text { Sugar cane, rust of } & \ldots & \ldots & \ldots & \ldots & \ldots & \ldots & \ldots & & 28\end{array}$

Sweet potato, dry rot of $\quad \begin{array}{lllllllll} & \ldots & \ldots & \ldots & \ldots & \ldots & \ldots & 42\end{array}$

Sweet potato, leaf blight of $\quad \begin{array}{lllllllll} & \ldots & \ldots & \ldots & \ldots & \ldots & \ldots & 42\end{array}$

Sweet potato, leaf mould of $\quad \begin{array}{lllllllll} & \ldots & \ldots & \ldots & \ldots & \ldots & \ldots & & \text { I7 }\end{array}$

Sweet potato, stem rot of $\quad \begin{array}{lllllllll} & \ldots & \ldots & \ldots & \ldots & \ldots & \ldots & & 24\end{array}$

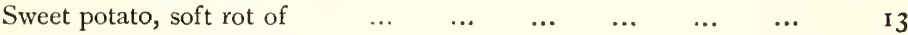

Sweet potato, root disease of $\begin{array}{llllllllll} & \ldots & \ldots & \ldots & \ldots & \ldots & \ldots & & 33\end{array}$

$\begin{array}{llllllllll}\text { Tania, disease of } & \ldots & \ldots & \ldots & \ldots & \ldots & \ldots & \ldots & & \text { 15 }\end{array}$

$\begin{array}{lllllllll}\text { Tea, horse-hair blight of } & \ldots & \ldots & \ldots & \ldots & \ldots & \ldots & & 33\end{array}$

$\begin{array}{lllllllll}\text { Thielaviopsis ethaceticus } & \ldots & \ldots & \ldots & \ldots & \ldots & \ldots & 56\end{array}$

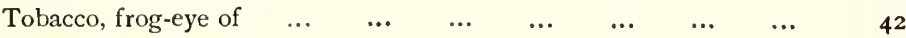

$\begin{array}{llllllllll}\text { Tobacco, leaf spot of } & \ldots & \ldots & \ldots & \ldots & \ldots & \ldots & \ldots & 54\end{array}$

Tobacco, mildew of $\quad \begin{array}{lllllllll} & \ldots & \ldots & \ldots & \ldots & \ldots & \ldots & \ldots & \text { I6 }\end{array}$

$\begin{array}{llllllllll}\text { Trichospheria Sachari... } & \ldots & \ldots & \ldots & \ldots & \ldots & \ldots & & \text { I9 }\end{array}$

$\begin{array}{lllllllll}\text { Uncinula spiralis } & \ldots & \ldots & \ldots & \ldots & \ldots & \ldots & \ldots & \\ \end{array}$ 
$\begin{array}{lllllllllll}\text { Uredo Arachidis } & \ldots & \ldots & \ldots & \ldots & \ldots & \ldots & \ldots & & \mathbf{2} 8\end{array}$

$\begin{array}{lllllllllll}\text { Uredo Canne } & \ldots & \ldots & \ldots & \ldots & \ldots & \ldots & \ldots & \ldots & 28\end{array}$

$\begin{array}{lllllllllll}\text { Uredo Gossypii } & \ldots & \ldots & \ldots & \ldots & \ldots & \ldots & \ldots & \ldots & \ldots & 29\end{array}$

$\begin{array}{lllllllllll}\text { Uredo Kühnii } & \ldots & \ldots & \ldots & \ldots & \ldots & \ldots & \ldots & \ldots & 28\end{array}$

$\begin{array}{llllllllll}\text { Ustilago Sacchari } & \ldots & \ldots & \ldots & \ldots & \ldots & \ldots & \ldots & 30\end{array}$

Watermelon, anthracnose of $\quad \begin{array}{llllllll} & \ldots & \ldots & \ldots & \ldots & \ldots & & \\ 46\end{array}$

$\begin{array}{llllllllll}\text { Watermelon, wilt of } & \ldots & \ldots & \ldots & \ldots & \ldots & \ldots & \ldots & 27\end{array}$ 




New York Botanical Garden Library

SB733.B3 C. 2

Bancroft, Keith/A handbook of the fungus

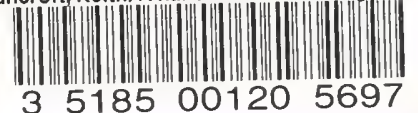

35185001205697 
